\title{
Credit Rating Downgrades and Sudden Stops of Capital Flows in the Eurozone
}

by Stefanos Ioannou*

\begin{abstract}
The current paper investigates the impact of sovereign ratings on sudden stops of capital in the context of the Eurozone. Our analysis focuses on the qualitative aspect of ratings, on the hypothesis that such aspect has a concrete impact on capital movements. A panel Probit model is utilized for our purposes. We separate between net and gross capital inflows, while we also draw a distinction between long-term and short-term oriented capital. Our results confirm the influence of sovereign ratings for the majority of our model specifications. They also appear to be most significant in the case of short-term flows.
\end{abstract}

Key Words: sovereign ratings; Eurozone; capital flows; sudden stops; Probit model

JEL Codes: C23; E44; F32; G24

“stefanos.ioannou@ouce.ox.ac.uk; Research Associate in Finance and Geography, School of Geography and the Environment, University of Oxford, South Parks Road, Oxford OX1 3QY 


\section{Introduction}

The sovereign ratings provided by the three main credit rating agencies (CRAs), namely Standard and Poor's (S\&P), Moody's and Fitch, have long been identified as an important source of financial instability. In the context of the East Asian crisis, Ferri et al. (1999) provide evidence of procyclical sovereign ratings, with previously inflated rating scores giving their place to exaggerated downgrades throughout the playing out of the crisis. Moreover, there is by now rich evidence showing how sovereign ratings feed into sovereign interest rate spreads (see Reisen and Maltzan, 1999; Gande and Parsley, 2005; Arezki et al., 2011; Afonso et al., 2012; De Santis, 2012; Baum et al., 2016). Interestingly, while the early papers of this stream were mostly focused on the developed world, a shift of attention towards the Eurozone economies can nowadays be observed. A less explored link is that between sovereign ratings, capital flows and investment. The few papers in this direction include Gande and Parsley (2004), Kim and Wu (2008) and Chen et al. (2013).

According to most of the abovementioned studies, rating downgrades tend to be more significant than upgrades in affecting financial outcomes. Especially when sharp, rating downgrades can substantially increase borrowing costs for national governments and adversely affect capital inflows towards the broader economy. Effectively, such behaviour can often act in a self-fulfilling manner by adding more pressure to economies already into financial distress.

Our paper contributes to the existing literature by further exploring the role of sovereign rating downgrades in sudden stops of capital, in the context of the Eurozone. This is a channel of influence that to the best of our knowledge has not been previously investigated. Our work is driven by two separate motivations: first, sudden stop episodes are commonly identified as one of the usual channels through which global financial turmoil 
stimulates a sovereign debt crisis (see for instance Reinhart and Rogoff, 2009 as found in Gros and Alcidi, 2015). Secondly, Eurozone provides us with a very recent and topical case study. The crisis that erupted in 2010 , and that is still to the current date being felt across the European periphery, has opened the space for questions which to a great part still remained unanswered.

There are three reasons why CRAs' own judgement matters at the first place. To start with, the costs of credit evaluation and monitoring are usually prohibitive for individual wealth owners. This is especially so in the case of short-term oriented investment funds with highly diversified portfolios. In response to the conundrum, CRAs make their appearance as an independent third party, offering exactly this type of services. Their voice comes to be seen as the voice of the "experts", and as a result CRAs gain an authoritative positioning in the financial market (also see Sinclair, 2005). Secondly, foreign investments usually involve a higher degree of uncertainty, as compared with domestic investment outlets, due to investors' partial knowledge of the economic and social conditions that surround foreign territories. Given that in theory CRAs' services aim at taming such uncertainty, their assessment should be expected to become even more pivotal in the case of international capital flows. This brings us straight to the topic of this paper. Third, perhaps the most straightforward aspect of all is the fact that credit ratings were until recently (and to a great extent still are) hardwired into financial regulation. This is a development that was initiated in the U.S. during the 1970s, when the three big rating agencies were recognised as official indicators of creditworthiness (see Sinclair, 2005 and White, 2010). In more recent times ratings also came to be formally incorporated into international and European financial regulation (a milestone in the process was the establishment of Basel II in 2004; for further details on European regulation see Lannoo, 2010). 
In this paper we are particularly interested in exploring the significance of the part of sovereign ratings that links with the qualitative analysis of CRAs. This is the part of rating making that primarily marks CRAs' own judgement, and thus relates with their temperament and psychology. In the broader picture, the distinct impact of psychology, expectations and uncertainty has long been identified in financial markets (for three of the most cornerstone contributions see Keynes, 1936; Kindleberger, 1978; and Minsky, 1986). Although tranquil periods can mask the importance of these aspects due to the prevalence of social conventions amongst market participants as to how the future is to look like, periods of turbulence bring them into the fore. Euphoric psychology can very sharply reverse into pessimism, while the evaporation of established conventions can amplify the uncertainty economic agents are faced with.

As defined by Keynes, uncertainty exposes the limits of probabilistic calculations. Certain events, unique in nature and/ or long term in scope, as for instance the occurrence of financial and political instability (e.g. Brexit), or in the words of Keynes "the price of copper and the rate of interest twenty years hence" (Keynes, 1937, p. 214), cannot be forecasted based on probabilistic calculus for the reason that the full set of information required for such computations does not exist in advance. This is a limitation in knowledge that is independent of the access an entity such as a CRA might have to a large pool of information.

In this canvas, our main hypothesis is that as with all other market participants, CRAs are also faced with the limitations associated with fundamental uncertainty. This implies that CRAs can equally well turn out to be over-optimistic in "good" times and over-pessimistic in "bad" ones. The paper of Ferri et al. (1999) discussed earlier is an example of such behaviour in the context of the East- Asian crisis (although based on a partly different interpretation). In what follows, we also identify evidence of over-downgrading for the 
countries of the European periphery from 2009 onwards (see Figure 3). This can be viewed as CRAs' distinct contribution to financial instability.

In terms of methodology, our paper follows Ferri et al. (1999) in breaking down sovereign ratings into a quantitative and a qualitative component (a distinction also pointed out by CRAs themselves; for relevant reports see S\&P, 2013; Fitch, 2014; Moody's, 2015), and in approximating the quantitative part of the ratings by regressing actual rating scores on a comprehensive set of macroeconomic fundamentals. The difference between actual and fitted ratings is then used as a proxy for sovereign ratings' qualitative component, and is inserted as an explanatory variable in a panel Probit model with random effects.

Our focus is on the original twelve countries of the Eurozone and the associated longterm sovereign ratings provided by the three CRAs. Moreover, our timespan starts from the genesis of the common currency and goes up to the end of 2012. This is a time period that takes into account the first and most severe phase of the European crisis, a period in which the vast majority of rating downgrades of the member states of the European periphery are clustered (the European periphery includes Greece, Italy, Ireland, Spain and Portugal).

Following the recent developments in sudden stop literature (see below), we consider not only net but also gross capital flows. The aim of the approach is to separate between the behaviour of domestic and foreign investors, and in that way allow ourselves to capture sudden stop episodes that could otherwise go unnoticed. Furthermore, we separate between FDI and non-FDI capital (the latter includes the 'portfolio' and 'other investment' accounts). The two categories of capital are different not only in their degree of liquidity, but also in their strategic scope. FDI flows are in principle associated with long- term productive investment in the hosting economy; as such they are less volatile and more immune to shortterm twists in market sentiment. On the other hand, non-FDI flows are short term in nature, associated with more liquid holdings. Portfolio investment for example encompasses most of 
the international secondary market trading of equity and debt securities, money market instruments and financial derivatives. Their focus on short-run gains implies that these capital flows are also more exposed to sudden changes in market sentiment. As such, they are more likely to be affected by changes in credit ratings (in the case of institutional investors such as pension funds, the impact of ratings is often quite direct due to the specific regulations governing their portfolio allocation). International lending and deposit holdings are also part of non-FDI flows, registered under the 'other investment' account.

Illustrated briefly, our findings suggest that the qualitative component of sovereign ratings is influential in determining episodes of sudden stops of capital in the Eurozone, irrespectively of the CRA under consideration. While the results are consistent both for total and non-FDI flows, it is in the case of the second where they become more conspicuous. This is in line with our earlier hypothesis. We also test our results by conducting three separate robustness checks. These include the utilization of a complementary logarithmic framework instead of the standard Probit model, the repetition of our regressions for the postcrisis era, and the modification of our binary variables specification.

The rest of the paper is organized as follows: the next section reviews the econometric literature on episodes of extreme capital flow movements. Following, section three outlines the relevant data and discusses in detail our approach in constructing the necessary binary variables. The subsequent part presents our econometric methodology. This is followed by the discussion of our results and the development of our robustness checks. The last part concludes.

All regressions of the paper are based on the "StataSE 13" software.

\section{Literature Review on Sudden Stops of Capital}


There has been a voluminous literature studying econometrically the occurrence of sudden stops of capital. Such literature has been primarily focused on developing countries (e.g. Calvo et al., 2004) due to the vulnerability of those states to sudden movements of foreign capital. An increasing interest towards the developed world and the Euro area more specifically, can also be observed during the more recent times (see for instance Forbes and Warnock, 2012a).

This literature treats episodes of extreme capital flow movements as something qualitatively different from continuous capital flow fluctuations. Thus, rather than employing a standard linear model that would amalgamate the dynamics of the two, relevant papers usually opt for binary response models. An advantage of this approach is the fact that binary response models allow for non-linear effects, so that a certain variable can have a different impact at different levels of the response variable (also see the discussion provided in the Econometric Methodology section of the paper). On the other hand, a puzzle exists in how one goes on to define episodes of extreme capital flow movements. It is easy to notice that any definition cannot but be arbitrary to an extent, so that different definitions can give rise to different results.

Although there are several modifications, most of the papers adopt a variant of the definition given by Calvo et al. (2004), as being one of the first and most cornerstone papers in this stream of literature. The basic version of their definition (Calvo et al., 2004, p. 14) flags a sudden stop as a "phase that meets the following conditions:

- It contains at least one observation where the year-on-year fall in capital flows lies at least two standard deviations below its sample mean (this addresses the "unexpected" requirement of a sudden stop). 
- The sudden stop phase ends once the annual change in capital flows exceeds one standard deviation below its sample mean. This will generally introduce persistence, a common fact of sudden stops.

- Moreover, for the sake of symmetry, the start of a sudden stop phase is determined by the first time the annual change in capital flows falls one standard deviation below the mean.'

At the empirical level, stressing the fact that sudden stops are mainly an emerging market phenomenon, Calvo and his colleagues point out trade openness and domestic liabilities denominated in US dollars as the two key factors behind such episodes. Furthermore, they link those variables with domestic fiscal and monetary policies, arguing that the deepest cause of such episodes comes from within rather than outside a country.

A series of subsequent papers support these findings, highlighting the importance of of other domestic factors. Amongst others, these papers include Broner and Rigobon (2005), Eichengreen et al. (2006), Frankel and Cavallo (2008), Catao and Milesi-Ferretti (2013) and Schmidt and Zwick (2013). Agosin and Huaita (2011) on the other hand offer a narrative in which the principal causality is attributed to the preceding surge of foreign capital.

An interesting development in the sudden stop as well as the broader capital flows literature is the recent shift of attention towards gross capital flows (see for instance Forbes and Warnock, 2012a, 2012b; Lane, 2013; Hannan, 2017). As pointed out by Forbes and Warnock (2012a, 2012b), the use of gross capital flows allows for a separation between the behaviour of domestic and foreign investors. It therefore becomes possible to identify episodes that would otherwise be missed out, as for instance the case where a sudden stop is counterbalanced by a simultaneous retrenchment in capital outflows. This is in agreement with Lane (2013) who points out the experience of Iceland, arguing that domestic financial risks can be intensified even if capital inflows are fully recycled into capital outflows. 


\title{
3. Data Outline and Binary Variables Construction
}

\author{
<Insert Figures 1 and 2 here>
}

Our panel consists of the twelve original countries of the Eurozone, and runs from 1999q1 and up to 2012q4 (quarterly frequency). Throughout this era the composition of international capital flows across Eurozone countries mainly consisted of non-FDI flows. Indicatively, the gross stock (assets plus liabilities) of portfolio investment in Greece was around three times the gross stock of FDI in that country in the beginning of 1999, with the ratio steadily rising to six to one by the end of 2007 (source: Eurostat). The same ratio grew from around 2.6 in early 1999 to 11.1 in late 2007 in Ireland. While the proportion of nonFDI investment was not as big in Germany, its gross stock was more than double than that of FDI throughout the same period.

From the perspective of macroeconomic and financial stability the dominance of nonFDI investment is particularly important due to the volatile and short-term investment scope of this type of capital (Agosin and Huaita, 2011). For this reason, one needs to separate these capital flows from the relatively more long-term oriented FDI. ${ }^{2}$ We also follow the most recent developments in literature by considering both net and gross flows.

For the construction of the binary variables of our model, we closely follow closely the approach developed by Forbes and Warnock (2012a; 2012b). In this direction, we take the 4-quarter moving sums for each series of capital flows $\left(F_{t}=\sum_{i=0}^{3} F L O W_{t-i}\right.$ for $t=$ $1999 q 1,1999 q 2, \ldots 2012 q 4)$ and then compute the year-over-year changes $\left(\Delta F_{t}=F_{t}-\right.$ $F_{t-4}$ for $\left.t=2000 q 1,2000 q 2, \ldots 2012 q 4\right)$. Following, we derive moving averages and

\footnotetext{
${ }^{2}$ Foreign Reserves are not taken into account since our focus is on the dynamics of the private sector.
} 
standard deviations, using a 5-year window (this is equivalent to 20 quarters, so that our computations employ 19 lags and the current value for each statistic).

Table 2 reports the summary statistics for each of the six series constructed. In addition, Figure 1 gives an idea of the fluctuations of the year-over-year change of net total flows (labelled as 'DTOTALNET') for Greece and Spain.

We then move to the construction of our sudden stop variables. In principle, other than following the guidelines established in relevant literature (see for instance Calvo et al., 2004; Forbes and Warnock, 2012a; 2012b), our idea is to construct those variables based on simple rules. Given the separation between gross inflows and gross outflows, a sudden stop of capital inflows is defined based on the following rules:

$$
\text { Sudden Stop }=\left\{\begin{array}{c}
1 \text { if } i) \Delta F_{i t}<\overline{\Delta F_{l}}-\sigma_{\Delta F_{i}} ; \text { ii) if } \Delta F_{i t}<\overline{\Delta F_{l}}-2 \sigma_{\Delta F_{i}} \\
\text { for at least } 1 \text { period during the interval } \\
\text { that satisfies the 1st condition; and } \\
\text { iii) if the total interval lasts at least } 2 \text { periods } \\
0 \text { otherwise }
\end{array}\right.
$$

where $\Delta F_{i t}$ is the year-over-year change of the flow under consideration (based on the moving sums of the quarterly observations) for country $i$ at time $t$, and $\overline{\Delta F_{l}}$ and $\sigma_{\Delta F_{i}}$ are the 5 years moving average and standard deviation values respectively. Given the above definitions, we derive four different varieties of sudden stop binaries. Relevant summary statistics are illustrated in Table 2, while the Appendix of the current reports the precise starting and ending point of each sudden stop episode for every country. As it can be seen in Table 2, there are significantly fewer episodes recorded when net flows are used.

Regarding the right hand variables, our aim is to test the economic and statistical significance of the long term sovereign ratings provided by the three main CRAs (Standard 
and Poor's, Moody's, and Fitch). Due the alphabetical ordering of those scores, a standard approach in empirical studies is to convert them into a linear arithmetical scale. ${ }^{3}$ The precise configuration (i.e. whether it is going to be 1 to 17 or 5 to 100 ) does not matter since the numbers are of an ordinal nature. Nevertheless, there can be some issues related with the efficiency of econometric estimations. This is pointed out by Afonso et al. (2007) who argue that it can be hard to estimate efficiently the threshold points between bottom rating categories due to the relevant scarcity of such observations. For this reason, they suggest putting into the same category all observations below B-. This is also what we do in the current by using the 1 to 17 scale for our estimations (see Table 1). We also take on board the credit outlook and watch scores provided by CRAs, by converting them into an extra 0.5 and 0.25 point respectively (added or subtracted depending on the occasion). Figure 2 presents the density histogram of the sovereign ratings of the three CRAs for the period examined, while Table 2 provides the relevant summary statistics.

Other than sovereign ratings, we also control for those domestic and global factors that are usually employed in relevant literature (see for instance Agosin and Huaita, 2011; Forbes and Warnock, 2012a and Schmidt and Zwick, 2013). Our list of domestic variables includes: per capita income, real GDP growth, external balance, fiscal balance, velocity of money, foreign reserves (measured as a ratio of imports), real effective exchange rate (REER; by definition this is the reverse measurement of competitiveness), inflation (measured in terms of divergence from the Eurozone average inflation at each point of time), interest rate spread (using the long term US interest rate as the basis so as to include Germany as well), gross external debt (measured over total exports), the share of non-FDI inflows, trade openness, public debt, credit growth, and the economic sentiment indicator (ESI) provided by Eurostat. Out of global variables we have included the US long term interest rate, the VIX

\footnotetext{
${ }^{3}$ Non-linear numerical transformations can also be found in literature (see for instance Ferri et al., 1999, Afonso, 2003 and Afonso et al., 2007). However as Afonso et al. (2007) report, results do not change much compared as with the linear specification.
} 
volatility index (a risk measurement published by the Chicago Board of Exchange), and the average G7 GDP growth rate.

Interestingly, although the expected impact of some variables, such as per capita income and real GDP growth, is quite straightforward, there are other variables whose sign could go either way. External balance for example could be seen with a negative sign, meaning that a current account deficit raises the probability of a sudden stop. Equally though, a current account deficit could be taken by investors as a "vote of confidence" to the prospects of the recipient country so that the sign of the variable gets reversed (or so that the variable becomes insignificant; recall here that by definition a current account deficit implies a net inflow of foreign capital). Similarly, a rising real effective exchange rate could be seen as a reflection of the increasing strength of the domestic economy, but could also be taken as an indication of declining competitiveness. Moreover, whether credit growth is sustainable or not might not be evident as such from the outset, especially to the extent that observed patterns unfold in a euphoric business climate. While of course one of the most important merits of the Probit specification is that it allows us to examine the marginal impact of each of these variables in conjunction with the values of all others, the point to be made here is that what becomes evident in retrospect (e.g. an unsustainable current account deficit) is not necessarily seen as such beforehand, at the time when investors decide where to allocate their wealth.

Tables 2 and 3 report the relevant summary statistics and the correlation matrix of all the control variables. The precise configuration of each measurement, along with all data resources are outlined in the Appendix.

<Insert Tables 1, 2 and 3 here> 


\section{Econometric Methodology}

Following the most common approach in literature, our paper utilizes a panel Probit model with random effects. Regarding our estimation strategy, our goal is to investigate the influence of the qualitative aspect of sovereign ratings upon sudden stops of capital. Notice that our separation between actual ratings and their qualitative component is not only economically intuitive, but also necessary from an econometrics point of view. This is because actual sovereign ratings are by definition instruments aiming to reflect the macroeconomic environment of a country at a given point of time. Putting them together with other macroeconomic variables would therefore create a serious issue of multicollinearity.

Our methodology involves the following two steps:

1. We first regress the actual sovereign ratings on a set of domestic macroeconomic fundamentals, using a linear fixed effects panel estimation. The decision as to which variables to include in our regressions is based upon the sovereign rating methodology reports published by rating agencies themselves (see S\&P, 2013; Fitch, 2014; Moody's, 2015) and the relevant empirical literature that aims to identify the key determinants of sovereign ratings (see the paragraph below).

Our variable selection process develops as follows: i) we regress the sovereign ratings of the three CRAs on a set of six time-varying variables that stand as the common denominator across the relevant empirical literature. These include per capita income, real GDP growth, fiscal balance, external balance, inflation and external debt. In essence this model replicates the one provided Cantor and Packer (1996) and Ferri et al. (1999), two of the most cornerstone articles in that stream. This is what appears as Model 1 in Table 4 below. In principle we would expect CRAs to attach a positive sign to the first four right hand side variables and a negative sign to external debt. Inflation should also 
be expected to be negatively related with ratings, albeit deflation is also recognised as a negative development by CRAs (see for instance Moody's, 2015); ii) we update the model by considering an extra set of six explanatory variables, extracted out of the most recent papers of the literature (see Afonso, 2003; Afonso et al., 2007; 2011; Canuto et al., 2012; Erdem and Varli, 2014; Montes et al., 2016). The new model is labelled as Model 2. On top of the abovementioned six variables, it also includes public debt, foreign reserves, trade openness, unemployment, domestic credit and government effectiveness. Other than including what recent scholars have found to be significant, the extended specification encompasses variables from all the families of variables that CRAs claim to use in their analyses (the precise categorizations are similar but not identical; for instance S\&P, 2013 uses a classification of five groups, separating between political, economic, external, fiscal, and monetary variables). Regarding their interpretation, we expect CRAs to view foreign reserves, trade openness, and government effectiveness in a positive way. On the other hand, we would expect public debt and unemployment to have an adverse effect on ratings. With respect to the stock of domestic credit (measured in proportion to GDP), we would also in theory anticipate a minus. As discussed above though, the ratio could turn out to be insignificant, on the hypothesis that unsustainable credit growth might not be evident ex-ante; iii) we narrow down Model 2 by dropping these variables that are statistically insignificant and that exhibit high levels of multicollinearity. Our primary aim here is to remove all the unnecessary noise. The Variance Inflation Factor (VIF) is used as our criterion here, with 10 playing the role of the threshold value (Baum, 2006). The new model is labelled as Model 3.

Table 4 summarizes the results. In the vast majority of cases right hand side variables appear with their anticipated signs. One notable exception is the negative sign that accompanies fiscal balance in Model 3. A simple explanation here comes out of the fact 
that even triple-A rated countries such as Germany experienced sizeable fiscal deficits during the 2000s, especially throughout the 2008/09 period when the financial crisis erupted. As for domestic credit, the lack of any noteworthy significance is in line with our earlier remarks.

2. We store the residuals of Model 3 for each rating agency, and plug them in our Probit models as an additional explanatory variable, along with all the other domestic and global variables reported earlier. The virtue of Model 3 is that it is inclusive of all significant determinants of sovereign ratings and up-to-date in terms of the variables reported in relevant literature (in contrast to Model 1). It is also econometrically sound (contrary to Model 2). Figure 3 illustrates the residual ratings of S\&P for a selection of EMU countries based on Model 3. In terms of interpretation, a positive (negative) residual implies a rating score that is higher (lower) from what the abovementioned set of fundamentals would justify.

Overall, the merit of our approach is twofold: first, it enables us to approximate the qualitative aspect of sovereign ratings by removing the quantitative component associated with the macroeconomic fundamentals discussed above. In that respect it is very helpful in terms of economic intuition. Secondly, it deals with a very important econometric issue by tackling the high multicollinearity between the actual ratings and the rest of the control variables that would otherwise occur in our Probit specifications. As it can be seen from Table 5, the levels of correlation between the ratings and the rest of the explanatory variables are substantially reduced when the rating residuals of Model 3 are considered for each agency instead of their actual ratings.

The following section reports the results for three varieties of our Probit model per rating agency. The first is a basic version, inclusive of the rating residuals of Model 3 and the global factors mentioned in sudden stop literature. The second is an extension which adds all 
the domestic control variables discussed above. Lastly, the third model subtracts the variables that exhibit high correlations, so as to ensure the accuracy of our estimated results. This process is repeated for all four types of sudden stop episodes, based on net and gross total and non-FDI flows. Throughout all our specifications all right-hand variables are introduced with a lag so as to tackle the issue of endogeneity.

$<$ Insert Figure 3 here>

<Insert Tables 4 to 9 here>

\section{Results}

The results reported in tables 6 to 9 show that in the majority of cases sovereign ratings turn out to be significant in explaining sudden stops of capital flows in the Eurozone, even after filtering out their quantitative component. In particular, we observe that out of the four ways of capturing sudden stop events (can be done in terms of i) net total flows, ii) net non-FDI flows, iii) gross total inflows and iv) gross non-FDI inflows), sovereign ratings appear to be important in three configurations.

When measured in terms of net total flows (Table 6), the sovereign ratings of Moody's and Fitch are significant at the 5\% and $10 \%$ levels respectively, when all other variables are included into our model. Although there is a drop in significance when the model is adjusted for excessive multicollinearity, Moody's ratings retain the biggest part of their significance (the relevant $\mathrm{t}$ - statistic is -1.80). According to this specification, was Moody's to over-downgrade the average country of our sample by one notch (i.e. downgrade it by one notch more than what the macroeconomic fundamentals of the country would justify), the probability of a sudden stop would increase by $16.5 \%$. 
The statistical significance of sovereign ratings is further consolidated when sudden stop episodes are measured in terms of non-FDI flows (see Tables 7 and 9). This is consistent with what we would expect in terms of economic intuition, given the shorttermism of such flows. First, in the case of net non-FDI flows the evidence suggests that the ratings of all three rating agencies are significant at either the $5 \%$ or the $10 \%$ levels when included in the third (excessive multicollinearity- adjusted) model. The significance of all specifications is further raised when sudden stop episodes are considered within the frame of gross non-FDI inflows (Table 9). Under the third model, the rating scores of all CRAs appear significant, with t-statistics between 1.71 and 2.11 (in absolute values) and with marginal effects close to $-20 \%$. The relevant regression for S\&P for example shows that a one notch over-downgrading by the agency raises the probability of a sudden stop episode by $20.7 \%$. In addition, the statistical significance of Moody's and Fitch ratings reaches the $1 \%$ level under the second, all-inclusive model (in the case of Moody's the t-statistic is higher than 3 in absolute terms). Throughout all the above specifications ratings are also economically meaningful in that they consistently appear with a minus.

With regards to the remaining variables of our models, we observe that out of the global factors the global uncertainty index VIX appears to be insignificant (this is in accordance with Schmidt and Zwick, 2013). In contrast, the G7 GDP growth rate appears to be the only noteworthy global determinant of sudden stop episodes. However, its significance varies according to specification. It therefore seems that in the overall global factors are not much important in shaping sudden stops. Out of the domestic factors, real GDP growth appears as one of the most important factors, while credit growth also seems to be playing a role in fuelling the dynamics that lead to a sudden stop. Additionally, our analysis shows that when included in our specification, external debt is highly significant and with a positive sign for three out of the four ways of measuring sudden stops. Similarly, 
trade openness exhibits some noteworthy significance in two out of the four specifications, while appearing with a minus.

\section{$<$ Insert Table 10 here>}

\subsection{Robustness Checks}

We now conduct a number of robustness checks. We first repeat all regressions for sudden stop episodes using a complementary logarithmic transformation (cloglog) instead of assuming a normal distribution as in the case of the baseline Probit model. The cloglog approach allows for asymmetry as well as for fatter tails in the two ends of the cumulative distribution. In that spirit, recent literature (Forbes and Warnock, 2012a, 2012b; Schmidt and Zwick, 2013) has recommended it as a more suitable approach for capturing events of capital flow reversals, given the scarcity of the latter.

Secondly, we break our sample in the first quarter of 2008 and repeat all regressions for the post crisis era (2008q1- 2012q4). This gives a panel with a time span of twenty observations, which although small can still allow us to draw some basic inference.

Third, we repeat our baseline regressions under alternative specifications for the sudden stop variables. So far all our binary variables have been based on the most widespread definition of the relevant literature (as established by Calvo et al., 2004). The virtue of such approach is that it provides a common denominator between present and past findings, which in turn is of great value in facilitating comparison. Nonetheless, as pointed out earlier, any definition is to an extent arbitrary. In that regard an important test of robustness is to see whether the reported results are fragile to the specification of the binary variables. To conduct such test, we alter the second condition of our baseline sudden stop definition, by shifting the two standard deviation threshold up and down by ten percent. This gives rise to two alternative scenarios. Under the first (second) one a sudden stop episode 
needs to contain at least one observation where the year-on-year fall in capital flows lies at least 1.8 (2.2) standard deviations below the sample mean. In both cases the first and third criteria remain as before. Namely, a sudden stop episode lasts as long as the year-on-year fall lies lower than one standard deviation below the mean, while any recorded episode needs to contain at least two time periods.

Starting with the cloglog regressions, we can see in the upper-left part of Table 10 that our results remain essentially unchanged. All specifications that were found significant above manage to retain their significances, with the model based on gross non-FDI inflows exhibiting the highest significance for our sovereign rating variables. Moreover, across all specifications ratings keep appearing with the proper sign (minus).

With respect to the post-crisis subsample some significance is lost in the models based on net capital flows. However, as illustrated in upper-right part of Table 10, the significance of all ratings variables is considerably boosted for all the models that are based on gross flows. Especially in the case of gross non-FDI inflows, we obtain robust significances at the $1 \%$ level across all CRAs and for almost all model specifications.

Furthermore, the bottom half of Table 10 reports the results for the alternative specifications of sudden stop episodes. While the first definition returns insignificant results for almost all regressions, the reverse holds true for the second specification. When setting the threshold of the second condition to a 2.2 standard deviation distance below the mean, the statistical significance of all rating variables is not only retained, but also strengthened for the vast majority of cases, as compared with the baseline results. Most notably, all regressions for gross non-FDI inflows give significant results for the rating variables of all CRAs at the $1 \%$ level. In addition, all the immune to excessive multicollinearity regressions (third column for each CRA) give significant results for all net flows. In all cases the economic significance is also retained in that the rating variables consistently appear with a minus sign. All in all, 
while such evidence shows that the baseline results reported earlier are not irrelevant to the definition of sudden stop episodes, it also shows that they are not dependent upon a specific binary construction either.

\section{Conclusion}

Our paper contributes to the sovereign rating and sudden stop literature by further exploring the influence of sovereign ratings on sudden stops of capital in the Eurozone. Our research encompasses the twelve original member states of the Eurozone and concentrates on the sovereign rating announcements provided by the three big CRAs (S\&P, Moody's and Fitch). Our timespan goes from the launch of the Euro to the end of 2012. This is a period that includes the most severe phase of the European crisis throughout which the great majority of severe downgrades are concentrated. Moreover, our baseline methodology involves a panel Probit model with random effects.

The main focus of our paper is on the part of sovereign ratings that reflects the qualitative analysis of CRAs. This choice serves two ends. First, it allows us to concentrate on the part of rating evaluations that associate with the agencies' own temperament; their own distinct contribution to financial stability or instability, outside the part of ratings that reflects the standard macroeconomic and political measurements. This intuition links with the role of psychology and expectations long identified in financial markets (see for instance Keynes, 1936). Secondly, by decomposing the ratings and isolating the qualitative aspect of ratings, the approach enables the incorporation of sovereign ratings along with other macroeconomic variables into the same econometric model, without facing the multicollinearity that would otherwise arise. 
Results are on the affirmative for the majority of the econometric specifications, and for all three CRAs. Most notably, sovereign ratings appear to be significant for three out of the four ways of capturing sudden stop episodes (namely for the cases of net total flows, net non-FDI flows and gross non-FDI flows). Results are strengthened when considering nonFDI instead of total flows. In addition, sovereign ratings appear with economically meaningful signs (minus) under all specifications.

A number of robustness checks are conducted so as to safeguard our results. These include: i) the repetition of the key regressions under a complementary logarithmic transformation; ii) the re-estimation of the model for the period 2008q1-2012q4, so as to account for the possibility of a structural break in the time series; and iii) the repetition of the baseline regressions under alternative specifications for the left- hand binary (sudden stop) variable: given the unavoidable arbitrariness that to an extent governs the construction of a binary variable, the intuition here is to see whether the results are dependent upon a particular specification or not. Under all robustness checks, the key results remain qualitatively similar.

The exploration of the research hypothesis discussed here in a broader geographical context could be an interesting extension of the current paper. In addition, the incorporation of the relevant empirical findings into a formal macroeconomic model could be another promising line for future research.

\section{Acknowledgements}

I am particularly grateful to Malcolm Sawyer and Gary Dymski for their fruitful guidance and support. I would also like to thank the participants of the weekly seminars organised by the Economics division of the University of Leeds, as well as one anonymous referee for their constructive remarks on an earlier draft of the paper. The paper has benefited from funding 
from the University of Leeds (University Research Scholarship) and from the European Research Council (European Union's Horizon 2020 research and innovation programme; grant agreement No. 681337).

\section{References}

Afonso, A (2003). Understanding the Determinants of Sovereign Debt Ratings: Evidence for the Two Leading Agencies. Journal of Economics and Finance, 27, 56- 74

Afonso, A, P Gomes and P Rother (2007). What "Hides" Behind Sovereign Debt Ratings?. ECB Working Paper Series, Working Paper No. 711, retrieved in the $9^{\text {th }}$ of April 2017 from https://www.repository.utl.pt/bitstream/10400.5/2134/1/ecbwp711.pdf

Afonso, A, P Gomes and P Rother (2011). Short- and Long-Run Determinants of Sovereign Debt Credit Ratings. International Journal of Finance and Economics, 16, 1- 15

Afonso, A, D Furceri and P Gomes (2012). Sovereign Credit Ratings and Financial Market Linkages; Application to European Data. Journal of International Money and Finance, 31, 606- 638

Agosin, M and F Huaita (2011). Capital flows to emerging economies: Minsky in the tropics. Cambridge Journal of Economics, 35, 663- 683

Arezki, R, B Candelon and A Sy (2011). Sovereign Rating News and Financial Markets Spillovers: Evidence from the European Debt Crisis. IMF Working Paper No. 
11/68, retrieved in the $10^{\text {th }}$ of June 2017 from http://www.imf.org/external/pubs/ft/wp/2011/wp1168.pdf

Baum, C (2006). An Introduction to Modern Econometrics Using Stata. Texas: Stata Press

Baum, C, D Schäfer and A Stephan (2016). Credit Rating Agency Downgrades and the Eurozone Sovereign Debt Crises. Journal of Financial Stability, 24, 117- 131

Broner, F and R Rigobon (2005). Why Are Capital Flows So Much More Volatile in Emerging than in Developed Countries?. Working Papers Central Bank of Chile, Working Paper No. 328, retrieved in the $6^{\text {th }}$ of April 2017 from http://si2.bcentral.cl/public/pdf/documentos-trabajo/pdf/dtbc328.pdf

Calvo, GA, A Izquierdo and L Mejia (2004). On the Empirics of Sudden-Stops: The Relevance of Balance-Sheet Effects. NBER Working Paper 10520, retrieved in

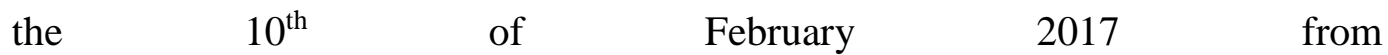
http://www.frbsf.org/economics/conferences/0406/Calvo.pdf

Cantor, R and F Packer (1996). Determinants and Impact of Sovereign Credit Ratings. Federal Reserve Bank of New York Economic Policy Review, issue Oct, 37- 53, retrieved in the $4^{\text {th }}$ of July 2017 from http://faculty.nps.edu/relooney/3040_2.pdf

Canuto, O, P Dos Santos and P De Sa Porto (2012). Macroeconomics and Sovereign Risk Ratings. Journal of International Commerce Economics and Policy, 3 
Catao, L and M Milesi- Ferretti (2013). External Liabilities and Crises. IMF Working Paper, WP/13/113, retrieved in the $5^{\text {th }}$ of June 2017 from http://www.imf.org/external/pubs/ft/wp/2013/wp13113.pdf

Chen, SS, HY Chen, CC Chang and SY Yang (2013). How Do Sovereign Credit Rating Changes Affect Private Investment?. Journal of Banking \& Finance, 37, 48204833

De Santis, R (2012). The Euro Area Sovereign Debt Crisis: Safe Haven, Credit Rating Agencies and the Spread of the Fever from Greece, Ireland and Portugal. ECB Working Paper Series, Working Paper No. 1419, retrieved in the $3^{\text {rd }}$ of June 2017 from http://www.ecb.europa.eu/pub/pdf/scpwps/ecbwp1419.pdf

Eichengreen, B, P Gupta and A Mody (2006), 'Sudden-Stops and IMF-Supported Programs', IMF Working Paper, WP/06/101, retrieved in the $10^{\text {th }}$ of April 2017 from http://www.imf.org/external/pubs/ft/wp/2006/wp06101.pdf

Erdem, O and Y Varli (2014). Understanding the Sovereign Credit Ratings of Emerging Markets. Emerging Markets Review, 20, 42- 57

Ferri, G, LG Liu and J Stiglitz (1999). The Procyclical Role of Rating Agencies: Evidence from the East Asian Crisis. Economic Notes, 28, 335- 355

Fitch Ratings (2014). Sovereign Rating Criteria: Master Criteria. Retrieved in the $20^{\text {th }}$ of September 2016 from 
https://www.fitchratings.com/creditdesk/reports/report_frame_render.cfm?rpt_id $=754428$

Frankel, J and E Cavallo (2008). Does Openness to Trade Make Countries More Vulnerable to Sudden Stops, or Less? Using Gravity to Establish Causality. Journal of International Money and Finance, 27, 1430- 1452

Forbes, K and F Warnock (2012a). Capital Flow Waves: Surges, Stops, Flight and Retrenchment. Journal of International Economics, 88, 235- 251

Forbes, K and F Warnock (2012b). Debt- And Equity-Led Capital Flow Episodes. NBER Working Paper Series, Working Paper 18329, retrieved in the $11^{\text {th }}$ of May 2017 http://www.nber.org/papers/w18329.pdf

Gande, A and D Parsley (2005). News Spillovers in the Sovereign Debt Market. Journal of Financial Economics, 75, 691- 734

Gande, A and D Parsley (2004). Sovereign Credit Ratings and International Portfolio Flows. Owen Graduate School of Management, Vanderbilt University, retrieved in the $15^{\text {th }} \quad$ of $\quad$ May $\quad 2017$ from http://www.imf.org/external/np/seminars/eng/2004/ecbimf/pdf/parsle.pdf

Gros, D and C Alcidi (2015). Country Adjustment to a "Sudden Stop": Does the Euro Make a Difference?. International Economics and Economic Policy, 12, 5- 20 
Hannan, SA (2017). The Drivers of Capital Flows in Emerging Markets Post Global Financial Crisis. IMF Working Paper, WP/17/52, retrieved in the $10^{\text {th }}$ of July 2017 from https://www.imf.org/en/Publications/WP/Issues/2017/03/10/TheDrivers-of-Capital-Flows-in-Emerging-Markets-Post-Global-Financial-Crisis-

$\underline{44739}$

Keynes, JM (1936). The General Theory of Employment, Interest and Money. Cambridge: Cambridge University Press, 1973

Keynes, JM (1937). The General Theory of Employment. The Quarterly Journal of Economics, 51, 209- 223

Kim, SJ and E Wu (2008). Sovereign Credit Ratings, Capital Flows and Financial Sector Development in Emerging Markets. Emerging Markets Review, 9, 17- 39

Kindleberger, C (1978). Manias, Panics and Crises; A History of Financial Crises. New York: Macmillan

Lane, P (2013). Capital Flows in the Euro Area. European Commission Directorate General Economic and Monetary Affairs (DG ECFIN), European Economy Economic Papers 497, retrieved in the $11^{\text {th }}$ of May 2017 from http://ec.europa.eu/economy_finance/publications/economic_paper/2013/pdf/ecp 497_en.pdf 
Lannoo, K (2010). What Reforms for the Credit Rating Industry? A European Perspective. ECMI Policy Brief, No. 17/ October 2010, retrieved in the $10^{\text {th }}$ of July 2016 from http://www.ceps.eu/book/what-reforms-credit-rating-industry-europeanperspective

Minsky, H (1986). Stabilizing an Unstable Economy. New Haven, Connecticut: Yale University Press

Montes, G, D Oliveira and H De Mendonca (2016). Sovereign Credit Ratings in Developing Economies: New Empirical Assessment. International Journal of Finance \& Economics, 21, 382- 397

Moody’s Investors Service (2015). Sovereign Bond Ratings: Rating Methodology. retrieved in the $3^{\text {rd }}$ of $\quad$ March 2016 from https://www.moodys.com/researchdocumentcontentpage.aspx?docid=PBC_1866 44, available upon registration

Reinhart, C and K Rogoff (2009). This Time is Different: Eight Centuries of Financial Follies. Princeton: Princeton University Press

Reisen, H and J Maltzan (1999). Boom and Bust and Sovereign Ratings. International Finance, 2, 273- 293

Schmidt, T and L Zwick (2013). Uncertainty and Episodes of Extreme Capital Flows in the Euro Area. Economic Modelling, 48, 343- 356 
Sinclair, T (2005). The New Masters of Capital: American Bond Rating Agencies and the Politics of Creditworthiness. London: Cornell University Press

Standard and Poor's (2013). Sovereign Government Rating Methodology and Assumptions.

Retrieved in the $10^{\text {th }}$ of October 2016 from http://www.standardandpoors.com/prot/ratings/articles/en/us/?articleType=HTM L\&assetID=1245356394670, available upon registration

White, L (2010). Markets: The Credit Rating Agencies. Journal of Economic Perspectives, $24,211-226$ 


\section{Figures}
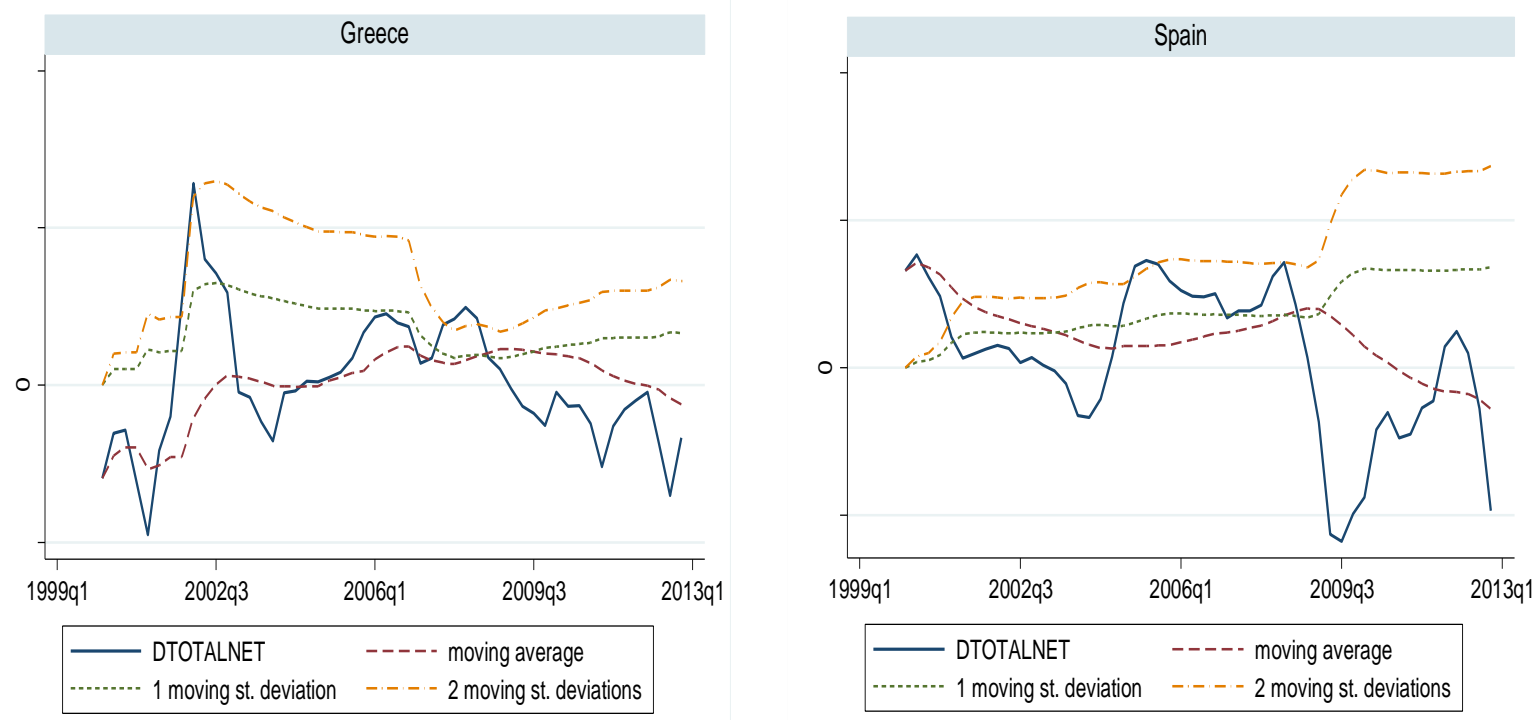

Figure 1. Year over Year change in Net Total Capital Flows for Greece and Spain (source: Eurostat and author's calculations)

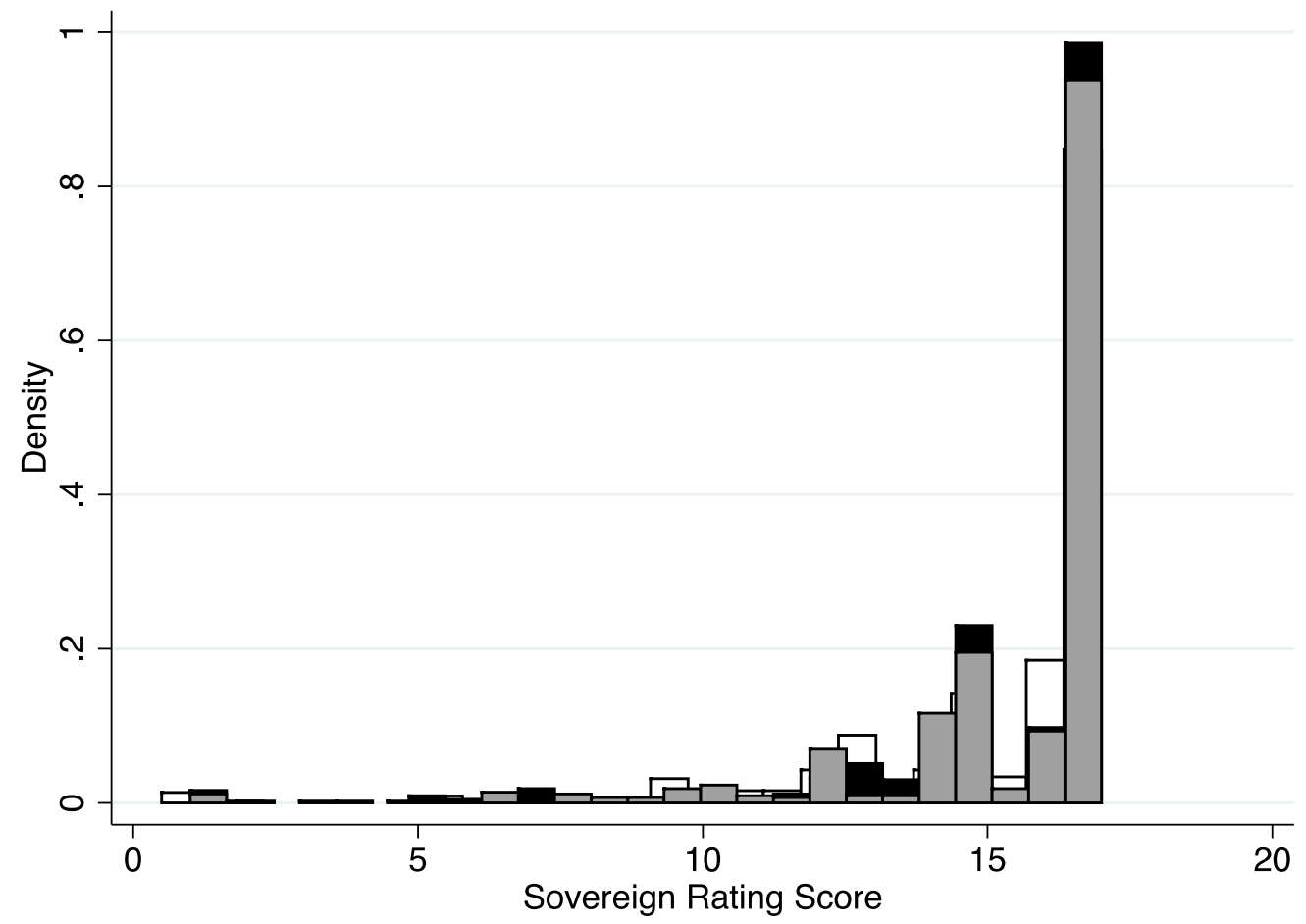

Figure 2. Density histogram of the sovereign ratings of S\&P (white), Moody's (black) and Fitch (grey) for the twelve Eurozone countries over the period 1999- 2012 (source: CRAs' websites and author's calculations) 


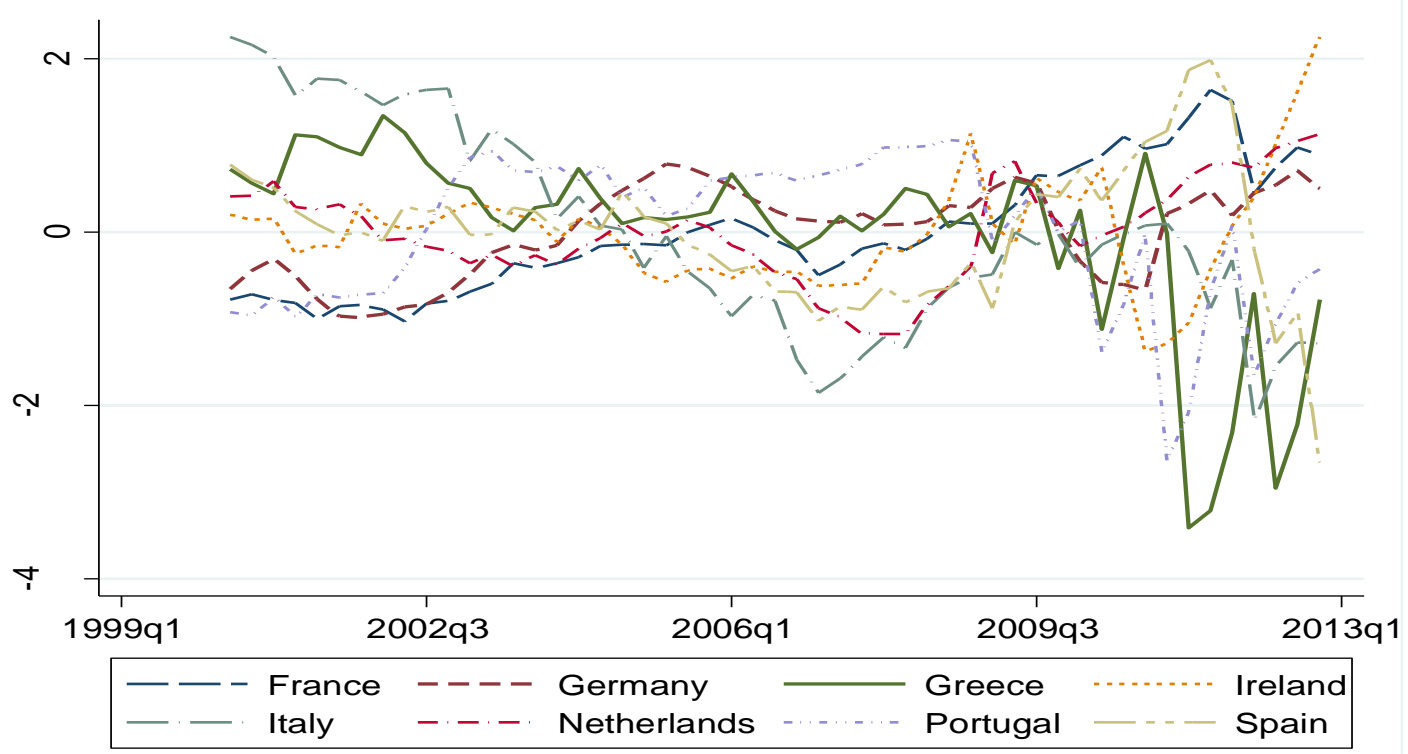

Figure 3. Standard and Poor's Residuals of Model 3 for a selection of EMU countries 


\section{Tables}

Table 1. Numerical Transformation of Sovereign Ratings

\begin{tabular}{|c|c|c|c|c|}
\hline credit quality & S\&P & Moody's & Fitch & 1-17 scale \\
\hline & long term & long term & long term & \\
\hline highest & AAA & Aaa & AAA & 17 \\
\hline \multirow[t]{3}{*}{ very high } & $\mathrm{AA}+$ & Aal & $\mathrm{AA}+$ & 16 \\
\hline & AA & $\mathrm{Aa} 2$ & $\mathrm{AA}$ & 15 \\
\hline & AA- & $\mathrm{Aa} 3$ & AA- & 14 \\
\hline \multirow[t]{3}{*}{ high } & $\mathrm{A}^{+}$ & A1 & $\mathrm{A}^{+}$ & 13 \\
\hline & A & $\mathrm{A} 2$ & A & 12 \\
\hline & A- & A3 & A- & 11 \\
\hline \multirow[t]{3}{*}{ good } & $\mathrm{BBB}+$ & Baa1 & $\mathrm{BBB}+$ & 10 \\
\hline & $\mathrm{BBB}$ & $\mathrm{Baa} 2$ & BBB & 9 \\
\hline & BBB- & $\mathrm{Baa} 3$ & BBB- & 8 \\
\hline \multirow[t]{3}{*}{ speculative } & $\mathrm{BB}+$ & $\mathrm{Ba} 1$ & $\mathrm{BB}+$ & 7 \\
\hline & $\mathrm{BB}$ & $\mathrm{Ba} 2$ & $\mathrm{BB}$ & 6 \\
\hline & BB- & $\mathrm{Ba} 3$ & BB- & 5 \\
\hline \multirow[t]{3}{*}{ highly speculative } & $\mathrm{B}+$ & $\mathrm{B} 1$ & $\mathrm{~B}+$ & 4 \\
\hline & $\mathrm{B}$ & $\mathrm{B} 2$ & $\mathrm{~B}$ & 3 \\
\hline & B- & B3 & B- & 2 \\
\hline \multirow[t]{3}{*}{ substantial credit risk } & $\mathrm{CCC}+$ & Caal & $\mathrm{CCC}+$ & \multirow[t]{7}{*}{1} \\
\hline & $\mathrm{CCC}$ & $\mathrm{Caa} 2$ & $\mathrm{CCC}$ & \\
\hline & $\mathrm{CCC}-$ & $\mathrm{Caa} 3$ & CCC- & \\
\hline very high level of credit risk & $\mathrm{CC}$ & $\mathrm{Ca}$ & $\mathrm{CC}$ & \\
\hline exceptionally high levels of credit risk & $\mathrm{C}$ & $\mathrm{C}$ & $\mathrm{C}$ & \\
\hline Selective/ Restricted Default & SD & & $\mathrm{RD}$ & \\
\hline Default & $\mathrm{D}$ & & $\mathrm{D}$ & \\
\hline \multicolumn{5}{|l|}{ Outlook/ Watch conversion } \\
\hline Positive Outlook & 0.5 & & & \\
\hline Credit Watch- Developing & 0.25 & & & \\
\hline Stable & 0 & & & \\
\hline Credit Watch- Negative & -0.25 & & & \\
\hline Negative Outlook & -0.5 & & & \\
\hline
\end{tabular}


Table 2. Summary Statistics

\begin{tabular}{|c|c|c|c|c|c|c|}
\hline & Variable & Obs & Mean & Std. Dev. & Min & Max \\
\hline \multirow{3}{*}{ 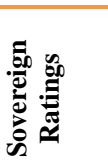 } & Standard and Poor's & 672 & 15.42 & 2.71 & 0.5 & 17 \\
\hline & Moody's & 672 & 15.63 & 2.68 & 1 & 17 \\
\hline & Fitch & 672 & 15.52 & 2.6 & 1 & 17 \\
\hline \multirow{6}{*}{ 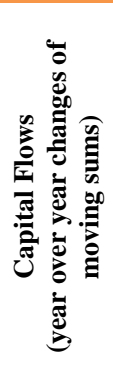 } & Net Total Inflows & 598 & 1119.84 & 27302.72 & -136115 & 215642 \\
\hline & Net non-FDI Flows & 598 & 131.67 & 36783.35 & -141648 & 167207 \\
\hline & Total Inflows & 598 & -3645.35 & 116810.2 & -709282 & 444119 \\
\hline & non-FDI Inflows & 598 & -4945.62 & 108832 & -655478 & 413390 \\
\hline & Total Outflows & 592 & -4288.77 & 118176.4 & -718749 & 424577 \\
\hline & Non-FDI Outflows & 598 & -5115.55 & 107046.6 & -606145 & 386519 \\
\hline \multirow{4}{*}{ 总 } & SSTNET & 588 & 0.1 & 0.3 & 0 & 1 \\
\hline & SSNFDINET & 588 & 0.09 & 0.29 & 0 & 1 \\
\hline & SSTIN & 588 & 0.15 & 0.36 & 0 & 1 \\
\hline & SSNFDIIN & 588 & 0.15 & 0.36 & 0 & 1 \\
\hline \multirow{15}{*}{ 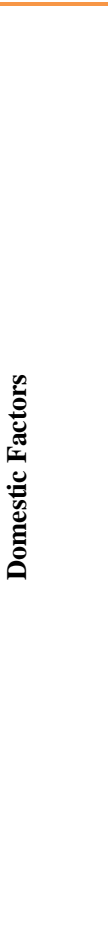 } & Per Capita Income & 672 & 29.53 & 13.26 & 10.55 & 82.3 \\
\hline & Real GDP Growth & 660 & 0.4 & 0.71 & -2.23 & 2.49 \\
\hline & Real Effective Exchange Rate & 660 & 0.18 & 1.21 & -6.97 & 7.35 \\
\hline & Inflation (divergence from Eurozone average) & 660 & 0.16 & 0.13 & 0 & 0.84 \\
\hline & $\begin{array}{l}\text { Interest Rate Spread } \\
\text { (based on the US long term rate) }\end{array}$ & 672 & 0.42 & 2.42 & -2.01 & 23.58 \\
\hline & External Balance & 660 & 0.05 & 5.94 & -15.53 & 14.85 \\
\hline & External Debt & 648 & 368.34 & 159.36 & 143.94 & 889.83 \\
\hline & Non-FDI share of Total Inflows & 635 & 0.77 & 0.27 & 0 & 1 \\
\hline & Trade Openness & 660 & 172.96 & 216.98 & 49.47 & 1072.91 \\
\hline & Foreign Reserves & 660 & 9.67 & 7.67 & -0.03 & 61.31 \\
\hline & Fiscal Balance & 672 & -2.51 & 4.33 & -27.65 & 6.75 \\
\hline & Public Debt & 624 & 67.35 & 31.82 & 5.42 & 174.41 \\
\hline & Credit Growth & 652 & 1.88 & 2.07 & -3.25 & 13.01 \\
\hline & Velocity & 664 & 1.06 & 0.42 & 0.14 & 2.15 \\
\hline & Economic Sentiment Indicator & 616 & 100.37 & 10.04 & 68.5 & 118.6 \\
\hline \multirow{3}{*}{ 푤 } & VIX & 672 & 21.86 & 8.19 & 11.39 & 44.14 \\
\hline & US long term interest rate & 672 & 4.14 & 1.14 & 1.64 & 6.48 \\
\hline & G7 GDP growth & 672 & 1.7 & 1.56 & -3.39 & 3.68 \\
\hline
\end{tabular}

Notes: SSTNET and SSNFDINET denote Sudden Stop episodes based on Net Total and non-FDI flows respectively, SSTIN and SSNFDIIN denote Sudden Stop episodes for gross Total and non-FDI inflows; Sources: Credit Rating Agencies'Eurostat, IMF IFS, CBOE and author's own calculations 
Table 3. Correlation Matrix of Control Variables

\begin{tabular}{|c|c|c|c|c|c|c|c|c|c|c|c|c|c|c|c|c|c|c|}
\hline & 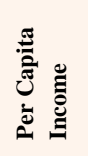 & 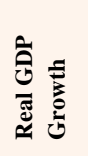 & 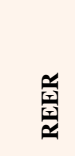 & 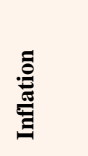 & 离 & 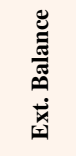 & 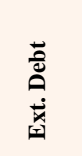 & 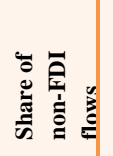 & 竧 & 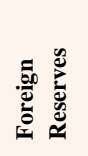 & 氖 & 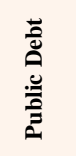 & 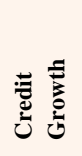 & 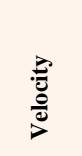 & 氛 & $\stackrel{x}{\partial}$ & 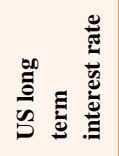 & 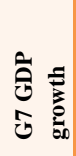 \\
\hline $\begin{array}{l}\text { Per Capita } \\
\text { Income }\end{array}$ & 1.00 & & & & & & & & & & & & & & & & & \\
\hline $\begin{array}{l}\text { Real GDP } \\
\text { Growth }\end{array}$ & 0.08 & 1.00 & & & & & & & & & & & & & & & & \\
\hline REER & 0.08 & 0.10 & 1.00 & & & & & & & & & & & & & & & \\
\hline Inflation & -0.09 & -0.02 & 0.00 & 1.00 & & & & & & & & & & & & & & \\
\hline $\begin{array}{l}\text { Interest Rate } \\
\text { Spread }\end{array}$ & -0.17 & -0.54 & -0.27 & 0.10 & 1.00 & & & & & & & & & & & & & \\
\hline $\begin{array}{l}\text { External } \\
\text { Balance }\end{array}$ & 0.66 & 0.22 & 0.04 & -0.12 & -0.23 & 1.00 & & & & & & & & & & & & \\
\hline $\begin{array}{l}\text { External } \\
\text { Debt }\end{array}$ & 0.30 & -0.28 & -0.12 & 0.14 & 0.36 & -0.30 & 1.00 & & & & & & & & & & & \\
\hline $\begin{array}{l}\text { Share of } \\
\text { non-FDI } \\
\text { flows }\end{array}$ & -0.21 & 0.07 & -0.03 & 0.10 & -0.07 & -0.19 & 0.03 & 1.00 & & & & & & & & & & \\
\hline $\begin{array}{l}\text { Trade } \\
\text { Openness }\end{array}$ & 0.93 & 0.10 & 0.05 & -0.02 & -0.11 & 0.48 & 0.47 & -0.19 & 1.00 & & & & & & & & & \\
\hline $\begin{array}{l}\text { Foreign } \\
\text { Reserves }\end{array}$ & -0.54 & -0.05 & -0.07 & 0.00 & 0.12 & -0.27 & -0.27 & 0.12 & -0.52 & 1.00 & & & & & & & & \\
\hline $\begin{array}{l}\text { Fiscal } \\
\text { Balance }\end{array}$ & 0.39 & 0.40 & 0.15 & 0.00 & -0.38 & 0.57 & -0.46 & -0.07 & 0.32 & -0.11 & 1.00 & & & & & & & \\
\hline Public Debt & -0.57 & -0.32 & -0.15 & -0.05 & 0.49 & -0.46 & 0.01 & 0.09 & -0.56 & 0.30 & -0.59 & 1.00 & & & & & & \\
\hline $\begin{array}{l}\text { Credit } \\
\text { Growth }\end{array}$ & 0.03 & 0.40 & 0.14 & 0.23 & -0.36 & -0.13 & 0.04 & 0.17 & 0.12 & -0.13 & 0.32 & -0.25 & 1.00 & & & & & \\
\hline Velocity & -0.55 & 0.11 & 0.07 & 0.04 & -0.08 & -0.13 & -0.55 & 0.17 & -0.65 & 0.50 & 0.17 & 0.28 & 0.08 & 1.00 & & & & \\
\hline ESI & -0.03 & 0.74 & 0.07 & -0.03 & -0.47 & 0.09 & -0.34 & 0.12 & -0.03 & 0.03 & 0.40 & -0.19 & 0.44 & 0.25 & 1.00 & & & \\
\hline VIX & -0.01 & -0.49 & 0.04 & 0.05 & 0.15 & -0.08 & 0.05 & -0.08 & -0.01 & 0.11 & -0.10 & 0.01 & -0.22 & -0.05 & -0.42 & 1.00 & & \\
\hline $\begin{array}{l}\text { US long term } \\
\text { interest rate }\end{array}$ & -0.21 & 0.50 & 0.10 & 0.16 & -0.45 & -0.01 & -0.31 & 0.15 & -0.10 & 0.07 & 0.38 & -0.23 & 0.48 & 0.33 & 0.60 & -0.18 & 1.00 & \\
\hline $\begin{array}{l}\text { G7 GDP } \\
\text { growth }\end{array}$ & -0.09 & 0.61 & -0.13 & 0.03 & -0.14 & 0.09 & -0.22 & 0.09 & -0.04 & 0.11 & 0.26 & -0.03 & 0.28 & 0.19 & 0.62 & -0.53 & 0.35 & 1.00 \\
\hline
\end{tabular}

Sources: Eurostat, IMF IFS, CBOE and author's calculations 
Table 4. Fixed Effects Panel Data Models for Sovereign Ratings

\begin{tabular}{|c|c|c|c|c|c|c|c|c|c|}
\hline & \multicolumn{3}{|c|}{ S\&P } & \multicolumn{3}{|c|}{ Moody's } & \multicolumn{3}{|c|}{ Fitch } \\
\hline & Model 1 & Model 2 & Model 3 & Model 1 & Model 2 & Model 3 & Model 1 & Model 2 & Model 3 \\
\hline \multirow{2}{*}{$\begin{array}{l}\text { Per Capita } \\
\text { Income }\end{array}$} & 0.05 & -0.002 & & 0.057 & -0.006 & & 0.06 & 0.014 & \\
\hline & $(0.87)$ & $(-0.06)$ & & $(0.89)$ & $(-0.11)$ & & $(1.02)$ & $(0.42)$ & \\
\hline \multirow{2}{*}{$\begin{array}{l}\text { Real GDP } \\
\text { Growth }\end{array}$} & $0.785^{*}$ & $0.425^{* *}$ & $0.546^{* * *}$ & $0.891^{*}$ & $0.472^{* *}$ & $0.467^{* *}$ & $0.710^{*}$ & $0.375^{* *}$ & $0.391^{* *}$ \\
\hline & $(2.02)$ & $(2.68)$ & (3.29) & (1.9) & $(2.32)$ & $(2.89)$ & $(1.96)$ & $(2.45)$ & $(2.92)$ \\
\hline \multirow[t]{2}{*}{ Inflation } & $-1.142^{*}$ & $-0.822^{* * *}$ & $-0.875^{* * *}$ & $-1.482^{*}$ & $-1.226^{* * *}$ & $-1.337^{* *}$ & -0.968 & $-0.817^{* *}$ & $-0.809^{*}$ \\
\hline & $(-1.97)$ & $(-3.94)$ & $(-3.61)$ & $(-2.11)$ & $(-3.34)$ & $(-3.04)$ & $(-1.60)$ & $(-2.36)$ & $(-2.11)$ \\
\hline \multirow{2}{*}{$\begin{array}{l}\text { Fiscal } \\
\text { Balance }\end{array}$} & 0.056 & $-0.153^{* * *}$ & $-0.132^{* * *}$ & 0.084 & $-0.161^{* *}$ & $-0.169 * * *$ & 0.063 & $-0.132^{* *}$ & $-0.132^{* *}$ \\
\hline & $(0.72)$ & $(-4.05)$ & $(-3.79)$ & $(0.97)$ & $(-2.94)$ & $(-3.41)$ & $(0.8)$ & $(-2.48)$ & $(-2.54)$ \\
\hline \multirow{2}{*}{$\begin{array}{l}\text { External } \\
\text { Balance }\end{array}$} & $-0.260^{* *}$ & 0.046 & & $-0.334^{* *}$ & 0.009 & & $-0.284^{* *}$ & -0.001 & \\
\hline & $(-2.79)$ & (1.1) & & $(-2.69)$ & $(0.14)$ & & $(-2.88)$ & $(-0.02)$ & \\
\hline \multirow{2}{*}{$\begin{array}{l}\text { External } \\
\text { Debt }\end{array}$} & $-0.008^{* *}$ & 0 & & $-0.007^{*}$ & 0.001 & & $-0.007^{*}$ & 0 & \\
\hline & $(-2.40)$ & $(0.18)$ & & $(-1.80)$ & $(0.45)$ & & $(-2.20)$ & $(0.19)$ & \\
\hline \multirow[t]{2}{*}{ Public Debt } & & $-0.090^{* * *}$ & $-0.090^{* * *}$ & & $-0.101^{* * *}$ & $-0.100^{* * *}$ & & $-0.081^{* * *}$ & $-0.082^{* * *}$ \\
\hline & & $(-7.70)$ & $(-7.31)$ & & $(-8.13)$ & $(-8.52)$ & & $(-7.39)$ & $(-7.68)$ \\
\hline \multirow{2}{*}{$\begin{array}{l}\text { Foreign } \\
\text { Reserves }\end{array}$} & & -0.019 & & & -0.026 & & & -0.019 & \\
\hline & & $(-0.69)$ & & & $(-0.63)$ & & & $(-0.56)$ & \\
\hline \multirow{2}{*}{$\begin{array}{l}\text { Unemploym } \\
\text { ent }\end{array}$} & & $-0.322^{* * *}$ & $-0.302^{* * *}$ & & $-0.376^{* * *}$ & $-0.376^{* * *}$ & & $-0.311^{* * *}$ & $-0.317^{* * *}$ \\
\hline & & $(-4.88)$ & $(-6.44)$ & & $(-4.12)$ & $(-5.35)$ & & $(-3.75)$ & $(-5.00)$ \\
\hline \multirow{2}{*}{$\begin{array}{l}\text { Govern- } \\
\text { ment } \\
\text { Effective- } \\
\text { ness }\end{array}$} & & 1.164 & & & 0.612 & & & 0.472 & \\
\hline & & (1.41) & & & $(0.76)$ & & & $(0.73)$ & \\
\hline \multirow{2}{*}{$\begin{array}{l}\text { Trade } \\
\text { Openness }\end{array}$} & & $0.006^{*}$ & $0.005^{* * *}$ & & $0.007^{*}$ & $0.005^{* * *}$ & & 0.004 & $0.005^{* * *}$ \\
\hline & & (2.08) & (3.91) & & (1.97) & $(4.38)$ & & (1.68) & (5.07) \\
\hline \multirow{2}{*}{$\begin{array}{l}\text { Domestic } \\
\text { Credit }\end{array}$} & & 0.001 & & & 0 & & & 0 & \\
\hline & & $(0.07)$ & & & $(0.05)$ & & & $(0.01)$ & \\
\hline \multirow[t]{2}{*}{ Constant } & $17.327^{* * *}$ & $21.466^{* * *}$ & $22.840^{* * *}$ & $17.036^{* * *}$ & $23.411^{* * *}$ & $24.449^{* * *}$ & $16.655^{* * *}$ & $21.932^{* * *}$ & $22.623^{* * *}$ \\
\hline & (16.08) & $(14.2)$ & (38.47) & (12.66) & (12.64) & (33.31) & (14.63) & (20.35) & $(41.52)$ \\
\hline $\mathbf{N}$ & 626 & 592 & 604 & 626 & 592 & 604 & 626 & 592 & 604 \\
\hline rho & 0.746 & 0.958 & 0.939 & 0.688 & 0.949 & 0.934 & 0.756 & 0.931 & 0.931 \\
\hline Mean VIF & 8.04 & 15.17 & 3.92 & 8.04 & 15.17 & 3.92 & 8.04 & 15.17 & 3.92 \\
\hline r2 overall & 0.102 & 0.488 & 0.477 & 0.05 & 0.361 & 0.426 & 0.067 & 0.451 & 0.46 \\
\hline r2 between & 0.379 & 0.565 & 0.498 & 0.483 & 0.444 & 0.445 & 0.407 & 0.541 & 0.463 \\
\hline r2 within & 0.404 & 0.851 & 0.837 & 0.364 & 0.816 & 0.811 & 0.397 & 0.815 & 0.812 \\
\hline
\end{tabular}

Notes: Numerical equivalent of the agency's sovereign rating is on the left hand of the regression; fixed effects and robust to heteroskedasticity standard errors are used; xtreg routine in STATA; all variables are defined in the Appendix; all right hand variables are included with a lag; t-statistics in parentheses; *, ** and *** denote significances at the $10 \%$, 5\% and $1 \%$ levels respectively. 
Table 5. Ratings and Ratings' Residuals Correlation Pairs

\begin{tabular}{|c|c|c|c|c|c|c|}
\hline & \multicolumn{3}{|c|}{ Actual Ratings } & \multicolumn{3}{|c|}{ Residual Ratings } \\
\hline & $\mathbf{S \& P}$ & Moody's & Fitch & S\&P & Moody's & Fitch \\
\hline Per Capita Income & 0.37 & 0.34 & 0.37 & -0.01 & 0.02 & 0.02 \\
\hline Real GDP Growth & 0.4 & 0.38 & 0.36 & 0.06 & 0.02 & 0.04 \\
\hline Real Effective Exchange Rate & 0.27 & 0.27 & 0.26 & 0.14 & 0.03 & 0.07 \\
\hline Inflation (divergence from Eurozone average) & -0.13 & -0.13 & -0.16 & -0.08 & -0.08 & -0.14 \\
\hline Interest Rate Spread (based on the US long term rate) & -0.8 & -0.84 & -0.8 & -0.34 & -0.26 & -0.31 \\
\hline External Balance & 0.52 & 0.45 & 0.49 & 0.03 & $\mathbf{0}$ & -0.02 \\
\hline External Debt & -0.47 & -0.42 & -0.44 & -0.04 & 0.06 & 0.04 \\
\hline Non-FDI share of Total Inflows & -0.07 & -0.03 & -0.06 & -0.04 & -0.01 & -0.02 \\
\hline Trade Openness & 0.21 & 0.19 & 0.21 & 0.01 & 0.01 & 0.01 \\
\hline Foreign Reserves & -0.19 & -0.19 & -0.17 & $\mathbf{0}$ & -0.08 & -0.06 \\
\hline Fiscal Balance & 0.57 & 0.52 & 0.54 & 0.01 & -0.08 & -0.1 \\
\hline Public Debt & -0.71 & -0.67 & -0.71 & -0.04 & 0.01 & $\mathbf{0}$ \\
\hline Credit Growth & 0.16 & 0.18 & 0.14 & 0.01 & -0.02 & -0.02 \\
\hline Velocity & 0.01 & 0.02 & 0 & 0.07 & -0.02 & $\mathbf{0}$ \\
\hline Economic Sentiment Indicator & 0.33 & 0.32 & 0.3 & 0.04 & 0.02 & 0.01 \\
\hline VIX & 0.01 & 0.02 & 0.02 & 0.1 & 0.05 & 0.06 \\
\hline US long term interest rate & 0.31 & 0.3 & 0.27 & 0.07 & -0.05 & -0.05 \\
\hline G7 GDP growth & 0.02 & -0.02 & -0.01 & -0.07 & -0.07 & -0.08 \\
\hline
\end{tabular}

Source: Eurostat, IMF, CBOE, CRAs' websites and author's elaboration 
Table 6. Models for Sudden Stops based on net Total Flows

\begin{tabular}{|c|c|c|c|c|c|c|c|c|c|c|}
\hline & & \multicolumn{3}{|c|}{ S\&P } & \multicolumn{3}{|c|}{ Moody's } & \multicolumn{3}{|c|}{ Fitch } \\
\hline & Rating & $-0.161 *$ & -0.03 & -0.09 & $-0.204 * *$ & $-0.288 * *$ & $-0.165^{*}$ & $-0.187^{*}$ & $-0.220^{*}$ & -0.15 \\
\hline & & $(-1.67)$ & $(-0.27)$ & $(-0.84)$ & $(-2.47)$ & $(-2.45)$ & $(-1.80)$ & $(-1.96)$ & $(-1.69)$ & $(-1.35)$ \\
\hline \multirow{6}{*}{ 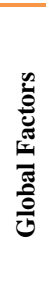 } & VIX & 0.00 & 0.01 & 0.00 & 0.00 & 0.01 & 0.00 & 0.00 & 0.01 & 0.00 \\
\hline & & $(0.14)$ & $(0.87)$ & $(0.16)$ & $(0.07)$ & $(0.98)$ & $(0.33)$ & $(0.01)$ & $(0.94)$ & $(0.23)$ \\
\hline & US interest rate & -0.06 & $0.761 * * *$ & & -0.07 & $0.710 * *$ & & -0.07 & $0.716 * *$ & \\
\hline & & $(-0.75)$ & (2.66) & & $(-0.84)$ & $(-2.49)$ & & $(-0.92)$ & $(2.55)$ & \\
\hline & G7 GDP growth & $-0.132 * * *$ & 0.00 & -0.07 & $-0.145 * * *$ & 0.00 & -0.07 & $-0.138 * * *$ & 0.00 & -0.07 \\
\hline & & $(-2.61)$ & $(0.01)$ & $(-1.04)$ & $(-2.82)$ & $(0.01)$ & $(-1.08)$ & $(-2.71)$ & $(0.04)$ & $(-1.03)$ \\
\hline \multirow{35}{*}{ 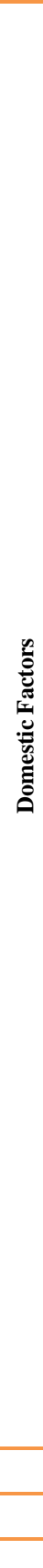 } & Per Capita Income & & $0.105^{*}$ & & & $0.093 *$ & & & $0.094 *$ & \\
\hline & & & (1.83) & & & (1.7) & & & $(1.72)$ & \\
\hline & GDP Growth & & -0.18 & $-0.419 * *$ & & -0.20 & $-0.457 * * *$ & & -0.22 & $-0.443 * *$ \\
\hline & & & $(-0.65)$ & $(-2.40)$ & & $(-0.72)$ & $(-2.58)$ & & $(-0.79)$ & $(-2.51)$ \\
\hline & REER & & -0.11 & $-0.179 * *$ & & -0.11 & $-0.185 * * *$ & & -0.11 & $-0.180 * *$ \\
\hline & & & $(-1.41)$ & $(-2.51)$ & & $(-1.40)$ & $(-2.59)$ & & $(-1.38)$ & $(-2.52)$ \\
\hline & Inflation & & $-2.491 * *$ & $-1.885 * * *$ & & $-2.538 * *$ & $-1.861 * * *$ & & $-2.715^{* * *}$ & $-1.991 * * *$ \\
\hline & & & $(-2.51)$ & $(-2.79)$ & & $(-2.49)$ & $(-2.73)$ & & $(-2.70)$ & $(-2.90)$ \\
\hline & US spread & & 0.10 & 0.02 & & 0.04 & 0.01 & & 0.06 & 0.01 \\
\hline & & & (1.53) & $(0.6)$ & & $(0.56)$ & $(0.18)$ & & $(0.87)$ & $(0.34)$ \\
\hline & Exterbal Balance & & $0.086^{* *}$ & $0.039 * *$ & & $0.106 * *$ & $0.037 * *$ & & $0.095^{* *}$ & $0.037 * *$ \\
\hline & & & (1.99) & $(2.11)$ & & (2.3) & (1.98) & & (2.16) & (1.99) \\
\hline & External Debt & & $0.004 * *$ & & & $0.005^{* *}$ & & & $0.005^{* *}$ & \\
\hline & & & (2.16) & & & $(2.49)$ & & & (2.33) & \\
\hline & Non-FDI & & $-0.524 *$ & -0.29 & & $-0.583 *$ & -0.29 & & $-0.552 *$ & -0.28 \\
\hline & & & $(-1.65)$ & $(-1.07)$ & & $(-1.83)$ & $(-1.07)$ & & $(-1.75)$ & $(-1.04)$ \\
\hline & Openness & & $-0.009 * *$ & & & $-0.009 * *$ & & & $-0.008 * *$ & \\
\hline & & & $(-2.28)$ & & & $(-2.37)$ & & & $(-2.30)$ & \\
\hline & Reserves & & 0.02 & 0.01 & & 0.02 & 0.01 & & 0.02 & 0.01 \\
\hline & & & $(0.66)$ & $(0.82)$ & & $(0.6)$ & $(0.8)$ & & $(0.72)$ & $(0.73)$ \\
\hline & Fiscal Balance & & -0.07 & $-0.071 * *$ & & -0.07 & $-0.072 * *$ & & -0.07 & $-0.073 * * *$ \\
\hline & & & $(-1.11)$ & $(-2.52)$ & & $(-1.12)$ & $(-2.56)$ & & $(-1.19)$ & $(-2.59)$ \\
\hline & Public Debt & & 0.01 & & & 0.01 & & & 0.01 & \\
\hline & & & $(0.82)$ & & & (1.1) & & & $(0.92)$ & \\
\hline & Credit Growth & & $0.122 *$ & $0.161 * * *$ & & $0.114 *$ & $0.161 * * *$ & & $0.114 *$ & $0.161 * * *$ \\
\hline & & & (1.92) & $(3.29)$ & & (1.76) & (3.27) & & (1.79) & (3.28) \\
\hline & Velocity & & -0.98 & & & -1.03 & & & -0.93 & \\
\hline & & & $(-1.48)$ & & & $(-1.56)$ & & & $(-1.47)$ & \\
\hline & ESI & & -0.01 & & & -0.01 & & & -0.01 & \\
\hline & & & $(-0.59)$ & & & $(-0.39)$ & & & $(-0.46)$ & \\
\hline & Constant & $-0.920 * *$ & $-6.250 * * *$ & $-1.199 * * *$ & $-0.844 * *$ & $-6.540 * * *$ & $-1.147 * * *$ & $-0.837 * *$ & $-6.301 * * *$ & $-1.158 * * *$ \\
\hline & & $(2.21)$ & $(2.65)$ & (2.92) & $(2.05)$ & $(2.70)$ & (2.77) & (2.04) & $(2.65)$ & $(2.81)$ \\
\hline & $\mathrm{N}$ & 578.00 & 515.00 & 565.00 & 578.00 & 515.00 & 565.00 & 578.00 & 515.00 & 565.00 \\
\hline & sigma_u & 0.16 & 0.57 & 0.00 & 0.17 & 0.61 & 0.00 & 0.16 & 0.55 & 0.00 \\
\hline & rho & 0.03 & 0.24 & 0.00 & 0.03 & 0.27 & 0.00 & 0.03 & 0.24 & 0.00 \\
\hline
\end{tabular}

Notes: The dependent variable is a binary one, taking the value of 1 if there is an episode, being 0 otherwise; the rating variables are the residual series of Model 3 from Table 4 of the current; the regressions reported here are based on the xtprobit routine in STATA; all variables are defined in the Appendix; all right hand variables are included with a lag; t-statistics in parentheses; *,** and *** denote significances at the $10 \%, 5 \%$ and $1 \%$ levels respectively 
Table 7. Models for Sudden Stops based on net non-FDI Flows

\begin{tabular}{|c|c|c|c|c|c|c|c|c|c|c|}
\hline & & \multicolumn{3}{|c|}{ S\&P } & \multicolumn{3}{|c|}{ Moody's } & \multicolumn{3}{|c|}{ Fitch } \\
\hline & Rating & $-0.377 * * *$ & -0.16 & $-0.349 * *$ & $-0.285 * * *$ & -0.18 & $-0.186^{*}$ & $-0.329 * * *$ & -0.11 & $-0.239 *$ \\
\hline & & $(-3.33)$ & $(-0.78)$ & $(-2.57)$ & $(-3.19)$ & $(-0.97)$ & $(-1.80)$ & $(-3.11)$ & $(-0.57)$ & $(-1.88)$ \\
\hline \multirow{6}{*}{ 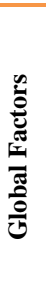 } & VIX & -0.02 & -0.02 & 0.00 & -0.02 & -0.01 & 0.00 & -0.02 & -0.02 & 0.00 \\
\hline & & $(-1.40)$ & $(-0.77)$ & $(0.21)$ & $(-1.51)$ & $(-0.63)$ & $(0.03)$ & $(-1.48)$ & $(-0.73)$ & $(0.12)$ \\
\hline & US interest rate & -0.05 & $1.720 * * *$ & & -0.05 & $1.757 * * *$ & & -0.06 & $1.731 * * *$ & \\
\hline & & $(-0.51)$ & (3.59) & & $(-0.59)$ & (3.67) & & $(-0.71)$ & (3.59) & \\
\hline & G7 GDP growth & $-0.255^{* * *}$ & $-0.496 * * *$ & $-0.451 * * *$ & $-0.257 * * *$ & $-0.464 * *$ & $-0.447 * * *$ & $-0.258 * * *$ & $-0.483^{* *}$ & $-0.451 * * *$ \\
\hline & & $(-4.57)$ & $(-2.65)$ & $(-5.25)$ & $(-4.58)$ & $(-2.47)$ & $(-5.25)$ & $(-4.61)$ & $(-2.57)$ & $(-5.28)$ \\
\hline \multirow{35}{*}{ 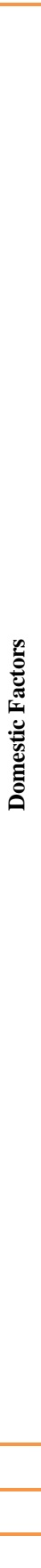 } & Per Capita Income & & -0.10 & & & -0.10 & & & -0.09 & \\
\hline & & & $(-0.66)$ & & & $(-0.60)$ & & & $(-0.54)$ & \\
\hline & GDP Growth & & $2.424 * * *$ & $1.045^{* * *}$ & & $2.285 * * *$ & $1.035 * * *$ & & $2.417 * * *$ & $1.049 * * *$ \\
\hline & & & $(3.28)$ & (3.71) & & (3.02) & $(3.70)$ & & $(3.25)$ & (3.76) \\
\hline & REER & & 0.09 & 0.14 & & 0.10 & 0.11 & & 0.09 & 0.11 \\
\hline & & & $(0.58)$ & (1.29) & & $(0.65)$ & (1.09) & & $(0.57)$ & (1.10) \\
\hline & Inflation & & $-3.850^{*}$ & $-1.760 *$ & & $-3.874^{*}$ & $-1.604 *$ & & $-3.874^{*}$ & $-1.758^{*}$ \\
\hline & & & $(-1.86)$ & $(-1.83)$ & & $(-1.86)$ & $(-1.69)$ & & $(-1.84)$ & $(-1.85)$ \\
\hline & US spread & & $1.214 * * *$ & $0.170^{* * *}$ & & $1.150 * * *$ & 0.182 *** & & $1.225 * * *$ & $0.177 * * *$ \\
\hline & & & (3.72) & (3.15) & & $(3.48)$ & $(3.46)$ & & (3.76) & $(3.33)$ \\
\hline & Exterbal Balance & & $0.160^{*}$ & 0.03 & & $0.168^{*}$ & 0.02 & & $0.164^{*}$ & 0.02 \\
\hline & & & (1.77) & $(0.7)$ & & (1.86) & $(0.38)$ & & $(1.81)$ & $(0.36)$ \\
\hline & External Debt & & 0.00 & & & 0.00 & & & 0.00 & \\
\hline & & & $(0.21)$ & & & $(0.10)$ & & & $(0.22)$ & \\
\hline & Non-FDI & & -0.08 & -0.16 & & -0.08 & -0.11 & & -0.05 & -0.11 \\
\hline & & & $(-0.16)$ & $(-0.46)$ & & $(-0.16)$ & $(-0.32)$ & & $(-0.10)$ & $(-0.34)$ \\
\hline & Openness & & 0.01 & & & 0.00 & & & 0.00 & \\
\hline & & & $(0.36)$ & & & $(0.31)$ & & & $(0.28)$ & \\
\hline & Reserves & & -0.04 & -0.01 & & -0.04 & -0.01 & & -0.04 & -0.01 \\
\hline & & & $(-0.68)$ & $(-0.25)$ & & $(-0.61)$ & $(-0.22)$ & & $(-0.61)$ & $(-0.22)$ \\
\hline & Fiscal Balance & & $-0.271 * *$ & 0.05 & & $-0.253 * *$ & 0.06 & & $-0.270 * *$ & 0.05 \\
\hline & & & $(-2.32)$ & (1.2) & & $(-2.18)$ & (1.37) & & $(-2.33)$ & $(1.26)$ \\
\hline & Public Debt & & $-0.140 * * *$ & & & $-0.134 * * *$ & & & $-0.144 * * *$ & \\
\hline & & & $(-3.01)$ & & & $(-2.84)$ & & & $(-3.10)$ & \\
\hline & Credit Growth & & $-0.396^{* *}$ & $-0.223^{* *}$ & & $-0.402^{* *}$ & $-0.201 *$ & & $-0.391 * *$ & $-0.204^{*}$ \\
\hline & & & $(-2.20)$ & $(-2.05)$ & & $(-2.23)$ & $(-1.89)$ & & $(-2.19)$ & $(-1.92)$ \\
\hline & Velocity & & $-5.420 * * *$ & & & $-5.719 * * *$ & & & $-5.590 * * *$ & \\
\hline & & & $(-3.20)$ & & & $(-3.45)$ & & & $(-3.35)$ & \\
\hline & ESI & & $-0.067 * *$ & & & $-0.064 * *$ & & & $-0.067 * *$ & \\
\hline & & & $(-2.23)$ & & & $(-2.12)$ & & & $(-2.20)$ & \\
\hline & Constant & -0.64 & $13.727 * *$ & -0.74 & -0.58 & $12.936^{*}$ & -0.74 & -0.55 & $13.708^{*}$ & -0.74 \\
\hline & & $(-1.33)$ & (1.96) & $(-1.23)$ & $(-1.23)$ & (1.8) & $(-1.25)$ & $(-1.16)$ & (1.91) & $(-1.26)$ \\
\hline & $\mathrm{N}$ & 578.00 & 515.00 & 565.00 & 578.00 & 515.00 & 565.00 & 578.00 & 515.00 & 565.00 \\
\hline & sigma_u & 0.45 & 6.72 & 0.78 & 0.46 & 6.61 & 0.72 & 0.47 & 6.79 & 0.72 \\
\hline & rho & 0.17 & 0.98 & 0.38 & 0.18 & 0.98 & 0.34 & 0.18 & 0.98 & 0.34 \\
\hline
\end{tabular}

Notes: The dependent variable is a binary one, taking the value of 1 if there is an episode, being 0 otherwise; the rating variables are the residual series of Model 3 from Table 4 of the current; the regressions reported here are based on the xtprobit routine in STATA; all variables are defined in the Appendix; all right hand variables are included with a lag; $t$-statistics in parentheses; *, ** and *** denote significances at the $10 \%, 5 \%$ and $1 \%$ levels respectively. 
Table 8. Models for Sudden Stops based on gross Total Inflows

\begin{tabular}{|c|c|c|c|c|c|c|c|c|c|c|}
\hline & & & $\mathbf{S \& P}$ & & & Moody's & & & Fitch & \\
\hline & Rating & -0.06 & -0.08 & 0.06 & -0.07 & -0.08 & 0.00 & -0.06 & -0.29 & 0.03 \\
\hline & & $(-0.65)$ & $(-0.40)$ & $(0.52)$ & $(-0.82)$ & $(-0.44)$ & $(0.01)$ & $(-0.67)$ & $(-1.32)$ & $(0.25)$ \\
\hline \multirow{6}{*}{ 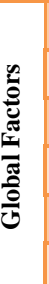 } & VIX & $0.039 * * *$ & 0.00 & 0.01 & $0.039 * * *$ & 0.00 & 0.01 & $0.039 * * *$ & 0.00 & 0.01 \\
\hline & & (4.44) & $(0.04)$ & $(1.17)$ & $(4.39)$ & $(0.01)$ & $(1.21)$ & $(4.41)$ & $(0.08)$ & $(1.19)$ \\
\hline & US interest rate & $0.250 * * *$ & $0.710 * *$ & & $0.244 * * *$ & $0.713 * *$ & & $0.244 * * *$ & $0.625 * *$ & \\
\hline & & $(3.01)$ & (2.29) & & (2.96) & (2.34) & & (2.95) & (2.04) & \\
\hline & G7 GDP growth & $-0.186^{* * * *}$ & -0.10 & -0.03 & $-0.186^{* * *}$ & -0.10 & -0.02 & $-0.186^{* * *}$ & -0.13 & -0.03 \\
\hline & & $(-3.89)$ & $(-0.94)$ & $(-0.37)$ & $(-3.90)$ & $(-0.93)$ & $(-0.34)$ & $(-3.89)$ & $(-1.17)$ & $(-0.35)$ \\
\hline \multirow{35}{*}{ 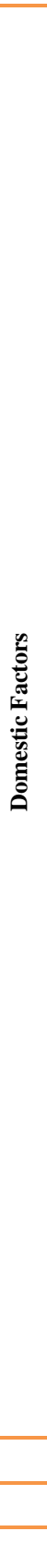 } & \multirow[t]{2}{*}{ Per Capita Income } & & 0.14 & & & 0.13 & & & 0.08 & \\
\hline & & & $(1.00)$ & & & $(0.90)$ & & & $(0.54)$ & \\
\hline & \multirow[t]{2}{*}{ GDP Growth } & & $-2.703 * * *$ & $-1.313 * * *$ & & $-2.692 * * *$ & $-1.313^{* * * *}$ & & $-2.767 * * *$ & $-1.317 * * *$ \\
\hline & & & $(-4.86)$ & $(-6.07)$ & & $(-4.88)$ & $(-6.05)$ & & $(-4.97)$ & $(-6.07)$ \\
\hline & \multirow[t]{2}{*}{ REER } & & 0.13 & 0.01 & & 0.13 & 0.01 & & 0.14 & 0.01 \\
\hline & & & $(1.27)$ & $(0.14)$ & & (1.26) & $(0.16)$ & & (1.31) & $(0.16)$ \\
\hline & \multirow[t]{2}{*}{ Inflation } & & $-2.633 * *$ & -0.39 & & $-2.572 * *$ & -0.40 & & $-2.749 * *$ & -0.39 \\
\hline & & & $(-2.28)$ & $(-0.58)$ & & $(-2.20)$ & $(-0.59)$ & & $(-2.38)$ & $(-0.57)$ \\
\hline & \multirow{2}{*}{ US spread } & & 0.13 & -0.07 & & 0.13 & -0.09 & & 0.07 & -0.08 \\
\hline & & & $(1.16)$ & $(-1.27)$ & & $(1.09)$ & $(-1.55)$ & & $(0.52)$ & $(-1.44)$ \\
\hline & \multirow[t]{2}{*}{ Exterbal Balance } & & $-0.230 * * *$ & $-0.074 * * *$ & & $-0.227 * * *$ & $-0.071 * * *$ & & $-0.223 * * *$ & $-0.072 * * *$ \\
\hline & & & $(-3.34)$ & $(-2.64)$ & & $(-3.28)$ & $(-2.61)$ & & $(-3.27)$ & $(-2.64)$ \\
\hline & \multirow[t]{2}{*}{ External Debt } & & $0.029 * * *$ & & & $0.029 * * *$ & & & $0.031 * * *$ & \\
\hline & & & $(4.64)$ & & & $(4.65)$ & & & $(4.74)$ & \\
\hline & \multirow[t]{2}{*}{ Non-FDI } & & $-1.053 * *$ & -0.46 & & $-1.048 * *$ & -0.47 & & $-1.133 * *$ & -0.47 \\
\hline & & & $(-2.42)$ & $(-1.53)$ & & $(-2.42)$ & $(-1.58)$ & & $(-2.55)$ & $(-1.57)$ \\
\hline & \multirow[t]{2}{*}{ Openness } & & 0.01 & & & 0.01 & & & 0.01 & \\
\hline & & & $(0.75)$ & & & $(0.78)$ & & & (1.07) & \\
\hline & \multirow[t]{2}{*}{ Reserves } & & $0.181 * * *$ & $0.035^{*}$ & & $0.179 * * *$ & $0.034 *$ & & $0.172 * * *$ & $0.035^{*}$ \\
\hline & & & $(3.91)$ & $(1.71)$ & & $(3.82)$ & $(1.65)$ & & (3.69) & $(1.69)$ \\
\hline & \multirow[t]{2}{*}{ Fiscal Balance } & & $0.234 * * *$ & $0.121^{* * * *}$ & & $0.233^{* * *}$ & $0.119 * * *$ & & $0.242 * * *$ & $0.121 * * *$ \\
\hline & & & (2.96) & (3.34) & & (2.98) & (3.28) & & (3.04) & (3.29) \\
\hline & \multirow[t]{2}{*}{ Public Debt } & & 0.02 & & & 0.02 & & & 0.03 & \\
\hline & & & $(0.89)$ & & & $(0.97)$ & & & (1.13) & \\
\hline & \multirow[t]{2}{*}{ Credit Growth } & & 0.20 & $0.123^{* *}$ & & 0.20 & $0.117 *$ & & 0.18 & $0.120 *$ \\
\hline & & & $(1.55)$ & $(1.98)$ & & $(1.59)$ & $(1.91)$ & & (1.44) & (1.94) \\
\hline & \multirow[t]{2}{*}{ Velocity } & & $10.082 * * *$ & & & $9.987 * * *$ & & & $10.504 * * *$ & \\
\hline & & & (3.87) & & & (3.88) & & & (4.06) & \\
\hline & \multirow[t]{2}{*}{ ESI } & & 0.02 & & & 0.02 & & & 0.03 & \\
\hline & & & $(0.94)$ & & & $(0.96)$ & & & $(1.24)$ & \\
\hline & \multirow[t]{2}{*}{ Constant } & $-2.745 * * *$ & $-35.058 * * *$ & $-0.996 * *$ & $-2.709 * * *$ & $-35.175 * * *$ & $-0.969 * *$ & $-2.714 * * *$ & $-35.929 * * *$ & $-0.977 * *$ \\
\hline & & $(-6.39)$ & $(-3.69)$ & $(-2.11)$ & $(-6.33)$ & $(-3.71)$ & $(-2.07)$ & $(-6.33)$ & $(-3.80)$ & $(-2.08)$ \\
\hline & $\mathrm{N}$ & 578.00 & 515.00 & 565.00 & 578.00 & 515.00 & 565.00 & 578.00 & 515.00 & 565.00 \\
\hline & sigma_u & 0.22 & 6.13 & 0.52 & 0.22 & 6.20 & 0.50 & 0.22 & 6.53 & 0.51 \\
\hline & rho & 0.05 & 0.97 & 0.21 & 0.05 & 0.98 & 0.20 & 0.05 & 0.98 & 0.21 \\
\hline
\end{tabular}

Notes: The dependent variable is a binary one, taking the value of 1 if there is an episode, being 0 otherwise; the rating variables are the residual series of Model 3 from Table 4 of the current; the regressions reported here are based on the xtprobit routine in STATA; all variables are defined in the Appendix; all right hand variables are included with a lag; $t$-statistics in parentheses; *, ** and *** denote significances at the $10 \%, 5 \%$ and $1 \%$ levels respectively. 
Table 9. Models for Sudden Stops based on gross non-FDI Inflows

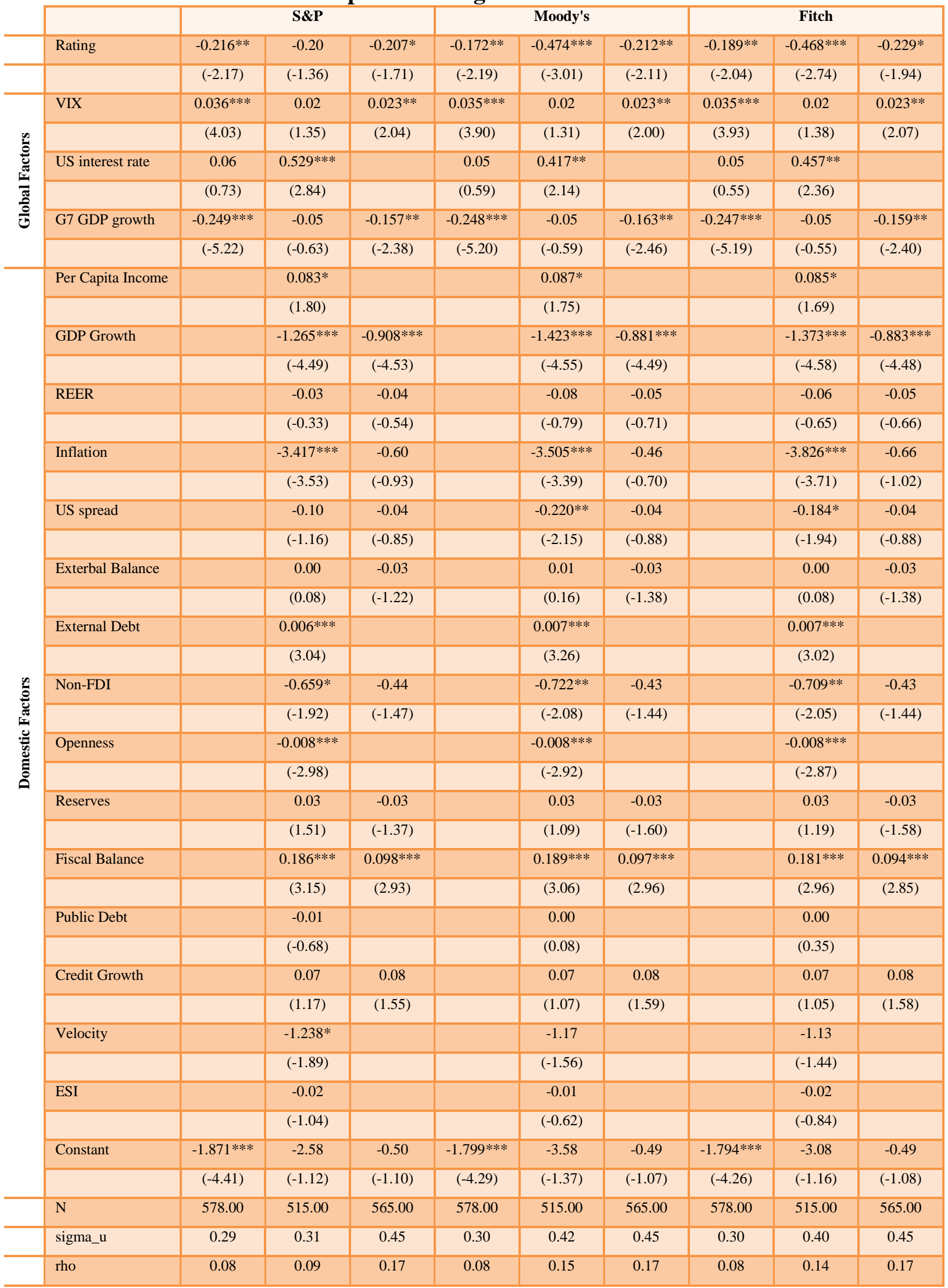

Notes: The dependent variable is a binary one, taking the value of 1 if there is an episode, being 0 otherwise; the rating variables are the residual series of Model 3 from Table 4 of the current; the regressions reported here are based on the xtprobit routine in STATA; all variables are defined in the Appendix; all right hand variables are included with a lag; $t$-statistics in parentheses; *, ** and *** denote significances at the $10 \%, 5 \%$ and $1 \%$ levels respectively. 
Table 10. Robustness Checks for the sovereign rating variables

\begin{tabular}{|c|c|c|c|c|c|c|c|c|c|c|c|c|c|c|c|c|c|c|}
\hline & \multicolumn{9}{|c|}{$\begin{array}{l}\text { Robustness Check 1: Sudden Stop Regressions based on the } \\
\text { Complementary Logarithmic Transformation (cloglog) }\end{array}$} & \multicolumn{9}{|c|}{ Robustness Check 2: Sudden Stop Regressions for the post-Crisis era (2008q1- 2012q4) } \\
\hline & \multicolumn{3}{|c|}{ S\&P } & \multicolumn{3}{|c|}{ Moody's } & \multicolumn{3}{|c|}{ Fitch } & \multicolumn{3}{|c|}{ S\&P } & \multicolumn{3}{|c|}{ Moody's } & \multicolumn{3}{|c|}{ Fitch } \\
\hline & 1st reg. & 2nd reg. & 3rd reg. & 1st reg. & 2nd reg. & 3rd reg. & 1st reg. & 2nd reg. & 3rd reg. & 1st reg. & 2nd reg. & 3rd reg. & 1 st reg. & 2nd reg. & 3rd reg. & 1st reg. & 2nd reg. & 3rd reg. \\
\hline \multirow{2}{*}{$\begin{array}{l}\text { Net } \\
\text { Total } \\
\text { Flows }\end{array}$} & $-0.320^{*}$ & -0.101 & -0.109 & $-0.324 * * *$ & $-0.394 * *$ & $-0.211^{*}$ & $-0.305^{* * *}$ & $-0.337 *$ & -0.155 & $-0.244 *$ & -0.189 & -0.131 & $-0.189^{*}$ & $-0.325^{* *}$ & -0.192 & -0.157 & -0.219 & -0.139 \\
\hline & $(-1.69)$ & $(-0.43)$ & $(-0.50)$ & $(-2.80)$ & $(-2.16)$ & $(-1.82)$ & $(-2.17)$ & $(-1.66)$ & $(-1.08)$ & $(-1.82)$ & $(-1.00)$ & $(-0.82)$ & $(-1.91)$ & $(-2.22)$ & $(-1.61)$ & $(-1.44)$ & $(-1.39)$ & $(-1.03)$ \\
\hline \multirow[t]{2}{*}{$\begin{array}{l}\text { Net } \\
\text { non-FDI } \\
\text { Inflows }\end{array}$} & $\underset{* *}{0.654^{*}}$ & $-0.547^{*}$ & $-0.592 * *$ & $-0.527 * * * *$ & -0.347 & $-0.364^{* * *}$ & $-0.542^{* * * *}$ & -0.468 & $-0.455^{*}$ & $-0.490^{* * * *}$ & -0.425 & -0.169 & $-0.418^{* * * *}$ & -0.294 & -0.172 & $-0.357 * * *$ & -0.14 & -0.057 \\
\hline & $(-4.00)$ & $(-1.93)$ & $(-2.25)$ & $(-3.50)$ & $(-1.55)$ & $(-2.03)$ & $(-3.49)$ & $(-1.63)$ & $(-1.85)$ & $(-2.65)$ & $(-1.39)$ & $(-0.60)$ & $(-3.14)$ & $(-1.31)$ & $(-0.92)$ & $(-2.58)$ & $(-0.63)$ & $(-0.28)$ \\
\hline \multirow{2}{*}{$\begin{array}{l}\text { Gross } \\
\text { Total } \\
\text { Inflows }\end{array}$} & -0.149 & 0.043 & -0.046 & -0.16 & 0.026 & -0.127 & -0.166 & -0.04 & -0.089 & $-0.370^{* * * *}$ & $-1.703^{* * *}$ & $-0.871 * * *$ & $-0.178^{*}$ & $-0.790^{* * *}$ & $-0.348^{*}$ & $-0.191 *$ & $-1.704 * * *$ & $-0.639 * * *$ \\
\hline & $(-0.90)$ & -0.2 & $(-0.25)$ & $(-1.30)$ & -0.13 & $(-0.85)$ & $(-1.07)$ & $(-0.20)$ & $(-0.51)$ & $(-2.67)$ & $(-3.29)$ & $(-3.25)$ & $(-1.80)$ & $(-2.55)$ & $(-1.85)$ & $(-1.71)$ & $(-3.20)$ & $(-2.75)$ \\
\hline \multirow[t]{6}{*}{$\begin{array}{l}\text { Gross } \\
\text { non-FDI } \\
\text { Inflows }\end{array}$} & $\begin{array}{c}0.297 * \\
*\end{array}$ & -0.233 & -0.199 & $-0.319^{* * * *}$ & $-0.551 * *$ & $-0.311^{* *}$ & $-0.335^{* *}$ & $-0.538^{* * *}$ & -0.287 & $-0.336^{* *}$ & $-0.803^{* * *}$ & $-0.548 * * *$ & $-0.249^{* * * *}$ & $-0.677^{* * * *}$ & $-0.445 * *$ & $-0.244 * *$ & $-0.897 * * *$ & $-0.582 * * *$ \\
\hline & $(-1.97)$ & $(-0.86)$ & $(-1.03)$ & $(-2.73)$ & $(-2.47)$ & $(-2.09)$ & $(-2.39)$ & $(-2.60)$ & $(-1.53)$ & $(-2.40)$ & $(-2.87)$ & $(-2.68)$ & $(-2.58)$ & $(-2.68)$ & $(-2.49)$ & $(-2.21)$ & $(-2.99)$ & $(-2.87)$ \\
\hline & \multicolumn{18}{|c|}{ Robustness Check 3: Sudden Stop Regressions with Alternative Definitions for the Binary Variables } \\
\hline & \multicolumn{6}{|c|}{ S\&P } & \multicolumn{6}{|c|}{ Moody's } & \multicolumn{6}{|c|}{ Fitch } \\
\hline & \multicolumn{2}{|c|}{1 st reg. } & \multicolumn{2}{|c|}{ 2nd reg. } & \multicolumn{2}{|c|}{ 3rd reg. } & \multicolumn{2}{|c|}{1 st reg } & \multicolumn{2}{|c|}{ 2nd reg. } & \multicolumn{2}{|c|}{ 3rd reg. } & \multicolumn{2}{|c|}{1 st reg } & \multicolumn{2}{|c|}{ 2nd reg. } & \multicolumn{2}{|c|}{ 3rd reg. } \\
\hline & $\begin{array}{l}1.8 \text { st. } \\
\text { dev. }\end{array}$ & $\begin{array}{l}2.2 \text { st. } \\
\text { dev. }\end{array}$ & $\begin{array}{l}1.8 \mathrm{st} \\
\text { dev. }\end{array}$ & $\begin{array}{l}2.2 \text { st. } \\
\text { dev. }\end{array}$ & $\begin{array}{l}1.8 \text { st. } \\
\text { dev. }\end{array}$ & $\begin{array}{l}2.2 \text { st. } \\
\text { dev. }\end{array}$ & $\begin{array}{l}1.8 \text { st. } \\
\text { dev. }\end{array}$ & $\begin{array}{l}2.2 \text { st. } \\
\text { dev. }\end{array}$ & $\begin{array}{l}1.8 \text { st. } \\
\text { dev. }\end{array}$ & $\begin{array}{l}2.2 \text { st. } \\
\text { dev. }\end{array}$ & $\begin{array}{l}1.8 \text { st. } \\
\text { dev. }\end{array}$ & $\begin{array}{l}2.2 \text { st. } \\
\text { dev. }\end{array}$ & $\begin{array}{l}1.8 \text { st. } \\
\text { dev. }\end{array}$ & $\begin{array}{l}2.2 \text { st. } \\
\text { dev. }\end{array}$ & $\begin{array}{l}1.8 \mathrm{st} \\
\text { dev. }\end{array}$ & $\begin{array}{l}2.2 \text { st. } \\
\text { dev. }\end{array}$ & $\begin{array}{l}1.8 \text { st. } \\
\text { dev. }\end{array}$ & $\begin{array}{l}2.2 \text { st. } \\
\text { dev. }\end{array}$ \\
\hline \multirow{2}{*}{$\begin{array}{l}\text { Net } \\
\text { Total } \\
\text { Flows }\end{array}$} & -0.137 & $-0.492^{* * * *}$ & 0.023 & $-0.616^{* * * *}$ & -0.007 & $-0.512^{* * *}$ & $-0.134 *$ & $-0.239 * * *$ & -0.12 & -0.055 & -0.056 & $-0.184 *$ & -0.134 & $-0.300 * * *$ & -0.095 & -0.07 & -0.032 & $-0.269 * *$ \\
\hline & $(-1.60)$ & $(-3.95)$ & $(+0.21)$ & $(-2.75)$ & $(-0.07)$ & $(-3.51)$ & $(-1.88)$ & $(-2.66)$ & $(-1.32)$ & $(-0.24)$ & $(-0.73)$ & $(-1.81)$ & $(-1.60)$ & $(-2.84)$ & $(-0.89)$ & $(-0.33)$ & $(-0.35)$ & $(-2.19)$ \\
\hline \multirow{2}{*}{$\begin{array}{l}\text { Net } \\
\text { non-FDI } \\
\text { Inflows }\end{array}$} & -0.119 & $-0.465 * * *$ & -0.105 & -0.357 & -0.013 & $-0.454 * * *$ & $-0.155^{*}$ & $-0.289 * * *$ & -0.045 & -0.301 & -0.035 & $-0.191^{*}$ & $-0.173^{*}$ & $-0.380^{* * * *}$ & -0.035 & -0.295 & -0.037 & $-0.302 * *$ \\
\hline & $(-1.25)$ & $(-3.84)$ & $(-0.79)$ & $(-1.35)$ & $(-0.12)$ & $(-2.99)$ & $(-1.95)$ & $(-3.20)$ & $(-0.40)$ & $(-1.62)$ & $(-0.41)$ & $(-1.83)$ & $(-1.83)$ & $(-3.49)$ & $(-0.27)$ & $(-1.41)$ & $(-0.34)$ & $(-2.26)$ \\
\hline \multirow{2}{*}{$\begin{array}{l}\text { Gross } \\
\text { Total } \\
\text { Inflows }\end{array}$} & -0.098 & -0.074 & -0.099 & -0.116 & -0.078 & 0.046 & -0.088 & -0.107 & -0.132 & $-0.640^{* *}$ & -0.127 & -0.116 & -0.128 & -0.098 & -0.266 & $-0.717 * * *$ & -0.154 & -0.119 \\
\hline & $(-1.10)$ & $(-0.71)$ & $(-0.73)$ & $(-0.51)$ & $(-0.79)$ & $(0.32)$ & $(-1.15)$ & $(-1.25)$ & $(-0.92)$ & $(-2.31)$ & $(-1.47)$ & $(-0.89)$ & $(-1.41)$ & $(-0.97)$ & $(-1.58)$ & $(-2.70)$ & $(-1.49)$ & $(-0.79)$ \\
\hline & -0.014 & $-0.342 * * *$ & 0.091 & $-0.323^{* *}$ & 0.079 & $-0.419 * * *$ & -0.09 & $-0.271^{* * *}$ & $-0.201 *$ & $-0.510^{* * *}$ & -0.079 & -0.460 *** & -0.071 & $-0.286 * * *$ & -0.141 & $-0.519^{* * * *}$ & -0.029 & $-0.511^{* * * *}$ \\
\hline $\begin{array}{l}\text { non-FDI } \\
\text { Inflows }\end{array}$ & $(-0.15)$ & $(-3.25)$ & $(+0.78)$ & $(-2.11)$ & $(+0.79)$ & $(-3.03)$ & $(-1.18)$ & $(-3.18)$ & $(-1.65)$ & $(-3.31)$ & $(-0.91)$ & $(-3.48)$ & $(-0.79)$ & $(-2.92)$ & $(-1.10)$ & $(-3.05)$ & $(-0.28)$ & $(-3.54)$ \\
\hline
\end{tabular}

Notes: The dependent variable is a binary one, taking the value of 1 if there is an episode, being 0 otherwise; only the sovereign rating variables are listed here; the rating variables are the residual series from the step-1 model of the current; cloglog routine in Stata used for robustness check 1; in robustness check 2 the total number of observations is 240 for the 1st regression, 211 for the 2 nd one, and 231 for the $3 r d$ one; in robustness check 3, the Probit results for two alternative definitions of sudden stops are reported. In the first (second) scenario an episode occurs if there is at least one period where the year-on-year fall in capital flows is greater than 1.8 (2.2) standard deviations below the mean. In both cases an episode lasts as long as the year-on-year fall is greater than a standard deviation below the mean, while any episode needs to consist of at least two time periods; in all robustness checks, similarly with the sequence of the main results, other than
the rating, the 1st regression includes the global factors only, the 2nd one includes all global and domestic factors, while the 3rd includes only those factors that are immune to multicollinearity; $;$-statistics in parentheses; *, ** and *** denote significances at the $10 \%, 5 \%$ and $1 \%$ levels respectively. 


\section{Appendix}

\section{A1. List of Sudden Stop Episodes per Country}

\begin{tabular}{|c|c|c|c|c|c|c|c|c|}
\hline & \multicolumn{2}{|c|}{$\begin{array}{l}\text { Sudden Stops of } \\
\text { Net Total Flows }\end{array}$} & \multicolumn{2}{|c|}{$\begin{array}{l}\text { Sudden Stops of Net } \\
\text { Non-FDI Flows }\end{array}$} & \multicolumn{2}{|c|}{$\begin{array}{c}\text { Sudden Stops of Total } \\
\text { Inflows }\end{array}$} & \multicolumn{2}{|c|}{$\begin{array}{l}\text { Sudden Stops of non- } \\
\text { FDI Inflows }\end{array}$} \\
\hline & Start & End & Start & End & Start & End & Start & End \\
\hline \multirow[t]{2}{*}{ Austria } & $2008 \mathrm{q} 1$ & $2008 \mathrm{q} 3$ & $2009 \mathrm{q} 3$ & 2010q1 & $2001 q 2$ & $2001 q 4$ & $2001 q 2$ & $2001 q 4$ \\
\hline & & & & & & & $2007 q 4$ & $2009 q 4$ \\
\hline \multirow[t]{3}{*}{ Belgium } & $2006 q 4$ & $2007 q 3$ & $2004 q 2$ & $2005 q 1$ & $2008 \mathrm{q} 4$ & $2009 q 3$ & $2008 \mathrm{q} 4$ & $2009 q 3$ \\
\hline & & & $2006 \mathrm{q} 3$ & $2007 \mathrm{q} 2$ & & & & \\
\hline & & & $2009 q 3$ & $2010 \mathrm{q} 2$ & & & & \\
\hline \multirow[t]{2}{*}{ Finland } & 2001q1 & $2001 q 4$ & $2009 q 4$ & $2010 \mathrm{q} 4$ & 2001q1 & $2001 q 4$ & $2009 q 2$ & $2009 \mathrm{q} 3$ \\
\hline & & & & & $2012 q 3$ & $2012 q 4$ & $2012 q 3$ & $2012 q 4$ \\
\hline France & $2007 q 1$ & $2008 \mathrm{q} 3$ & 2001q2 & $2002 q 1$ & $2008 \mathrm{q} 1$ & $2009 q 3$ & $2008 q 1$ & $2009 \mathrm{q} 3$ \\
\hline \multirow[t]{2}{*}{ Germany } & & & & & $2000 q 4$ & $2002 q 1$ & $2008 \mathrm{q} 3$ & $2009 q 3$ \\
\hline & & & & & $2008 \mathrm{q} 3$ & $2009 q 3$ & & \\
\hline Greece & $2010 q 2$ & $2011 \mathrm{q} 2$ & $2012 q 2$ & $2012 q 3$ & $2010 \mathrm{q} 2$ & 2011q2 & $2010 \mathrm{q} 2$ & $2011 \mathrm{q} 2$ \\
\hline \multirow[t]{3}{*}{ Ireland } & $2008 \mathrm{q} 4$ & $2009 \mathrm{q} 3$ & $2002 q 4$ & $2003 q 3$ & $2001 q 1$ & 2001q3 & $2000 q 4$ & $2003 q 2$ \\
\hline & & & & & $2004 q 4$ & $2005 q 1$ & $2007 q 4$ & $2009 q 3$ \\
\hline & & & & & $2008 \mathrm{q} 2$ & $2009 q 3$ & & \\
\hline \multirow[t]{3}{*}{ Italy } & $2000 \mathrm{q} 4$ & $2001 q 4$ & $2004 q 1$ & $2004 q 3$ & $2001 \mathrm{q} 3$ & $2002 q 2$ & $2002 q 1$ & $2002 q 2$ \\
\hline & $2009 q 4$ & $2010 \mathrm{q} 1$ & $2009 \mathrm{q} 2$ & $2010 \mathrm{q} 1$ & & & & \\
\hline & $2011 q 4$ & $2012 q 1$ & $2011 q 4$ & $2012 q 1$ & & & & \\
\hline \multirow[t]{2}{*}{ Luxembourg } & $2006 q 4$ & $2007 q 3$ & $2006 q 4$ & $2007 q 2$ & $2008 \mathrm{q} 2$ & $2009 \mathrm{q} 2$ & $2006 q 4$ & $2007 q 2$ \\
\hline & & & & & & & $2008 \mathrm{q} 2$ & $2009 q 2$ \\
\hline \multirow[t]{2}{*}{ Netherlands } & $2003 q 2$ & $2004 q 3$ & & & 2001q2 & $2002 q 4$ & $2007 q 4$ & $2009 q 3$ \\
\hline & $2009 q 2$ & $2009 q 4$ & & & $2008 \mathrm{q} 1$ & $2009 q 3$ & & \\
\hline \multirow[t]{3}{*}{ Portugal } & $2011 \mathrm{q} 2$ & $2012 q 4$ & $2012 q 1$ & $2012 q 4$ & $2002 q 2$ & $2003 q 2$ & $2002 q 4$ & $2003 q 3$ \\
\hline & & & & & $2004 q 3$ & $2005 q 2$ & $2005 q 1$ & $2005 q 2$ \\
\hline & & & & & $2010 q 4$ & 2011q3 & $2010 \mathrm{q} 4$ & $2011 q 4$ \\
\hline Spain & 2009q1 & 2010q1 & $2008 \mathrm{q} 3$ & 2010q1 & $2008 \mathrm{q} 1$ & $2009 q 3$ & $2007 q 4$ & $2009 \mathrm{q} 3$ \\
\hline
\end{tabular}




\section{A2. Description of Variables}

\begin{tabular}{|c|c|c|c|}
\hline $\begin{array}{l}\text { Net Total Capital Flows } \\
\text { (millions of Euro; source: } \\
\text { Eurostat) }\end{array}$ & $\begin{array}{l}\text { net FDI+ net Portfolio } \\
\text { Investment }+ \text { net Other } \\
\text { Investment }\end{array}$ & $\begin{array}{l}\text { Divergence of Inflation } \\
\text { Rate from Eurozone } \\
\text { Average (\% units: } \\
\text { source: International } \\
\text { Financial Statistics IMF) }\end{array}$ & $\begin{array}{l}\text { Inflation Growth Rate; Harmonized Consumer Price Index } \\
\text { used; differences from EMU average taken in square terms; } \\
\text { EMU inflation average computed by the author; seasonally } \\
\text { adjusted }\end{array}$ \\
\hline $\begin{array}{l}\text { Net non-FDI Capital Flows } \\
\text { (millions of Euro; source: } \\
\text { Eurostat) }\end{array}$ & $\begin{array}{l}\text { net Portfolio Investment } \\
+ \text { net Other Investment }\end{array}$ & $\begin{array}{l}\text { External Balance (\% } \\
\text { units; source: Eurostat) }\end{array}$ & (Current Account Balance/GDP)*100 \\
\hline $\begin{array}{l}\text { Total Capital Inflows } \\
\text { (millions of Euro; source: } \\
\text { Eurostat) }\end{array}$ & $\begin{array}{l}\text { FDI in Rep } \\
\text { Economy + } \\
\text { Portfolio } \quad \text { Investment } \\
\text { Liabilities }+ \text { Other } \\
\text { Investment Liabilities }\end{array}$ & $\begin{array}{l}\text { External Debt (\% units; } \\
\text { source: Eurostat) }\end{array}$ & $\begin{array}{l}\text { (External Debt/ Total Exports)*100; External Debt is } \\
\text { approximated by (portfolio account, debt instrument } \\
\text { liabilities+ other investment, liabilities); Total Exports are the } \\
\text { summary of (goods, credit+ services, credit+ income, credit); } \\
\text { quarterly ratio divided by } 4\end{array}$ \\
\hline $\begin{array}{l}\text { Total Capital Outflows } \\
\text { (millions of Euro; source: } \\
\text { Eurostat) }\end{array}$ & $\begin{array}{lr}\text { FDI Abroad+ } & \text { Portfolio } \\
\text { Investment } & \text { Assets+ } \\
\text { Other Investment Assets }\end{array}$ & $\begin{array}{l}\text { Public Debt (\% units; } \\
\text { source: Eurostat) }\end{array}$ & $\begin{array}{l}\text { (General Government Debt/ GDP)*100; Maastricht Debt used; } \\
\text { ratio divided by } 4\end{array}$ \\
\hline $\begin{array}{l}\text { Non-FDI Capital Inflows } \\
\text { (millions of Euro; source: } \\
\text { Eurostat) }\end{array}$ & $\begin{array}{l}\text { Portfolio Investment } \\
\text { Liabilities }+ \text { Other } \\
\text { Investment Liabilities }\end{array}$ & $\begin{array}{l}\text { Reserves (\% units; } \\
\text { source: Eurostat) }\end{array}$ & (Foreign Reserves/ Imports)*100; divided by 4 \\
\hline $\begin{array}{l}\text { Non-FDI Capital Outflows } \\
\text { (millions of Euro; source: } \\
\text { Eurostat) }\end{array}$ & $\begin{array}{lr}\text { Portfolio } & \text { Investment } \\
\text { Assets+ } & \text { Other } \\
\text { Investment } & \text { Assets }\end{array}$ & $\begin{array}{l}\text { Unemployment } \quad(\% \\
\text { units; source: Eurostat) }\end{array}$ & Total Unemployment Rate; seasonally adjusted \\
\hline $\begin{array}{l}\text { Sovereign Ratings (index } \\
\text { units: source: S\&P, } \\
\text { Moody's \& Fitch websites; } \\
\text { data available for free } \\
\text { upon subscription) }\end{array}$ & $\begin{array}{l}\text { Long Term Foreign } \\
\text { Currency Ratings }\end{array}$ & $\begin{array}{l}\text { Trade Openness (\% } \\
\text { units; source: Eurostat) }\end{array}$ & Measured as [(Exports+ Imports)/ GDP]*100 \\
\hline $\begin{array}{l}\text { Per Capita } \\
\text { (thousands of } \begin{array}{r}\text { Income } \\
\text { Source: Eurostat) }\end{array}\end{array}$ & $\begin{array}{l}\text { GDP at Mkt Prices/ } \\
\text { Population; quarterly } \\
\text { figures are seasonally } \\
\text { adjusted and multiplied } \\
\text { by } 4\end{array}$ & $\begin{array}{l}\text { Income Velocity of } \\
\text { Money. Measured as } \\
\text { GDP/ M2 (\% units: } \\
\text { source: International } \\
\text { Financial Statistics IMF) }\end{array}$ & $\begin{array}{l}\text { M2 approximated by the sum of currency under circulation+ } \\
\text { demand deposits+ other deposits; GDP multiplied by } 4 \text { in the } \\
\text { quarterly series }\end{array}$ \\
\hline $\begin{array}{l}\text { Real GDP Growth (\% } \\
\text { units; source: Eurostat) }\end{array}$ & $\begin{array}{l}\text { Real GDP }=\text { Nom } \\
\text { GDP/GDP Deflator * } \\
\text { 100; seasonally adjusted }\end{array}$ & $\begin{array}{lr}\text { Domestic } & \text { Credit } \quad(\% \\
\text { units: } & \text { source: } \\
\text { International } & \text { Financial } \\
\text { Statistics IMF) }\end{array}$ & $\begin{array}{l}\text { Measured as (Domestic Credit/GDP)*100; domestic credit } \\
\text { approximated by the "MFI claims to Other Sectors" account; } \\
\text { national residency criterion used }\end{array}$ \\
\hline $\begin{array}{l}\text { Real Effective Exchange } \\
\text { Rate (REER) (\% units; } \\
\text { source: Eurostat) }\end{array}$ & $\begin{array}{l}\text { deflator: unit labour } \\
\text { costs in } 37 \text { trading } \\
\text { partners }\end{array}$ & $\begin{array}{l}\text { Economic Sentiment } \\
\text { Indicator (index units; } \\
\text { source: Eurostat) }\end{array}$ & $\begin{array}{l}\text { qualitative measurement designed by Eurostat; based on } \\
\text { monthly interviews; seasonally adjusted by Eurostat itself; } \\
\text { converted by the author to quarterly frequency (from } \\
\text { monthly) by taking the last month of each quarter (e.g. March } \\
\text { for Q1, June for Q2 and so on) }\end{array}$ \\
\hline $\begin{array}{l}\text { Fiscal Balance (\% units; } \\
\text { source: Eurostat) }\end{array}$ & $\begin{array}{l}\text { [(Total Public Revenues- } \\
\text { Total Public Expenses }) / \\
\text { GDP] }]^{*} 100\end{array}$ & $\begin{array}{l}\text { VIX Volatility Index } \\
\text { (index units; source: } \\
\text { Chicago Board of } \\
\text { Exchange) }\end{array}$ & $\begin{array}{l}\text { designed by the Chicago Board of Exchange (CBOE), based on } \\
\text { a range of options' prices; for more information, see the FAQ } \\
\text { http://www.cboe.com/micro/vix/faq.aspx; converted by the } \\
\text { author to quarterly frequency (from monthly) by taking the } \\
\text { last month of each quarter (e.g. March for Q1, June for Q2 and } \\
\text { so on) }\end{array}$ \\
\hline $\begin{array}{lr}\text { Interest Rate } & \text { Spread } \\
\text { based on the US } & \text { rate }(\% \\
\text { units: } & \text { source: } \\
\text { International } & \text { Financial } \\
\text { Statistics IMF) } & \end{array}$ & $\begin{array}{l}\text { US long term } \\
\text { government yield } \\
\text { as a base }\end{array}$ & $\begin{array}{l}\text { G7 GDP Growth Rate (\% } \\
\text { units: source: } \\
\text { International Financial } \\
\text { Statistics IMF) }\end{array}$ & $\begin{array}{l}\text { the IMF constructs area and world indices by applying a } \\
\text { weighted average of country indices; see the IMF IFS manual } \\
\text { for more info; G7 countries include Canada, France, Germany, } \\
\text { Italy, Japan, UK, and USA; provided in annual frequency; } \\
\text { extrapolated to quarterly by the author }\end{array}$ \\
\hline $\begin{array}{l}\text { US Interest Rate (\% units: } \\
\text { source: International } \\
\text { Financial Statistics IMF) }\end{array}$ & $\begin{array}{l}\text { US long } \\
\text { government yield }\end{array}$ & 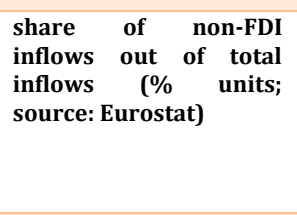 & $\begin{array}{l}\text { constructed by the author; formula used: } \\
\text { (PI+OI)/(PI+OI+FDI); ratio focuses exclusively on positive } \\
\text { inflows for the recipient countries so as to avoid extreme } \\
\text { values that wouldn't make sense. Hence whenever the inflow } \\
\text { would be negative ("stop") the value was set equal to zero; in } \\
\text { the cases where all inflows were negative, the ratio is not } \\
\text { provided; smoothing has been applied }\end{array}$ \\
\hline $\begin{array}{l}\text { Government Effectiveness } \\
\text { (index units; source: } \\
\text { World Bank) }\end{array}$ & \multicolumn{3}{|c|}{$\begin{array}{l}\text { Index reported in the World Governance Indicator Database; interpolated from annual to quarterly frequency; used } \\
1998 \text { as the entrance scores for 1999; copy pasted the } 2000 \text { values in } 2001 \text { cause the latter were missing }\end{array}$} \\
\hline
\end{tabular}

